\title{
Up-Regulation of Renin-Angiotensin System in Diabetes and Hypertension: Implications on the Development of Diabetic Nephropathy
}

\author{
Dulce Elena Casarini et al.* \\ Department of Medicine, Federal University of São Paulo, São Paulo
}

Brazil

\section{Introduction}

The growing worldwide epidemic of metabolic syndrome and other chronic degenerative diseases continues to expand, with a rapid decrease in the age at which they are being diagnosed (Guarnieri et al.; 2010; Hsueh \& Wyne, 2011). Metabolic syndrome is a multifactorial disorder, strongly influenced by several lifestyle factors, with symptoms clustering on abnormalities that include obesity, hypertension, dyslipidemia, glucose intolerance and insulin resistance (Guarnieri et al.; 2010; Tanaka et al.; 2006). The syndrome is also referred to as "Diabesity" highlighting the incidence of diabetes mellitus (DM) in combination with obesity as a result of changes in human behavior (Astrup \& Finer, 2000; Farag \& Gaballa, 2011; $\mathrm{Hu}, 2011)$.

Obesity is considered an independent predictor of the development of hypertension and it has been estimated that about half of individuals with essential hypertension are considered insulin resistant (Hall et al.; 2010; Kotsis et al.; 2010). Likewise, insulin resistance and hyperinsulinemia increase the risk of hypertension, and it usually accompanies DM, early in type 2 (DM2) and delayed in type 1 (DM1). Moreover, among patients being treated for hypertension, the risk of new-onset diabetes is doubled in those with uncontrolled blood pressure (BP) (Gress et al.; 2000; Gupta et al.; 2008; Izzo et al.; 2009). Although effective antihypertensive agents are available, achieving adequate BP control remains difficult in hypertensive patients, particularly in the context of concomitant diabetes.

It is widely known that individuals with DM and/or hypertension are prone to develop a broad range of long term complications, including cardiovascular disease and nephropathy (Farag \& Gaballa, 2011; Guarnieri et al.; 2010; Houston et al.; 2005; Handelsman, 2011; Tanaka et al.; 2006), and it has already been shown that several modifiable risk factors are associated with poor renal and cardiovascular outcome, including BP, plasma glucose and lipid concentrations, smoking, and body weight (Miao et al.; 2011). It is important to

\footnotetext{
${ }^{*}$ Danielle Yuri Arita ${ }^{1}$, Tatiana Sousa Cunha ${ }^{1,2}$, Fernanda Aparecida Ronchi ${ }^{1}$, Danielle Sanches Aragão1, Rodolfo Mattar Rosa ${ }^{1}$, Nadia Sousa Cunha Bertoncello ${ }^{1}$ and Fernanda Klein Marcondes ${ }^{3}$ ${ }^{1}$ Department of Medicine, Nephrology Division, Federal University of São Paulo, São Paulo, Brazil ${ }^{2}$ Science and Technology Institute, Federal University of São Paulo, São José dos Campos, Brazil ${ }^{3}$ Department of Physiological Sciences, Piracicaba Dental School, University of Campinas, Piracicaba, Brazil
} 
highlight that both DM and hypertension exacerbate each other in terms of subsequent complications (Cooper \& Johnston, 2000) increasing the burden of social dysfunction and high risk of premature death.

$\mathrm{DM}$ is a chronic metabolic disorder characterized by hyperglycemia and insufficiency of secretion or action of endogenous insulin. Nowadays, diabetes afflicts around $6.6 \%$ of the global adult population, or approximately 285 million individuals, and this is projected to increase by more than $50 \%$ to a $7.8 \%$ worldwide prevalence in 20 years. Considering that $\mathrm{DM}$ is an important health problem and it has been recognized as a major risk factor for the development of complications in target organs, including retinopathy, neuropathy, nephropathy and cardiovascular disease, the comprehension of the mechanisms involved in the association among diabetes is the subject of many research groups (International Diabetes Federation, 2009).

Of these complications, diabetic nephropathy (DN), the most common etiology of chronic kidney disease (CKD) and common cause of end-stage renal disease (ESRD) in adults in the Western world (Choudhury et al.; 2010; Cooper, 1998; National Institute of Diabetes and Digestive and Kidney Diseases, 2010), is associated with the highest mortality (Cooper, 1998; Giacchetti et al.; 2005) making early diagnosis critical in preventing long term kidney loss. Approximately $30 \%$ of patients with either DM1 or DM2 develop DN (Dalla Vestra et al.; 2000), and in these patients, lowering of BP and of urinary albumin excretion significantly decrease the risk of progression to ESRD, myocardial infarction and stroke (Choudhury et al.; 2010; Cooper et al.; 2000; Gupta et al.; 2008; Handelsman, 2011; Keller et al.; 1996).

Approximately $80 \%$ of individuals with diabetic ESRD are affected by hypertension, which accelerates the progression rate of renal disease (Jandeleit-Dahm \& Cooper, 2002). In DM1 the onset of hypertension appears to occur primarily as a consequence rather than as a primary cause of renal disease (Poulsen et al.; 1994). The link between glycemic control and the development of hypertension has been demonstrated in the follow-up of the landmark Diabetes Control and Complications Trial (DCCT), the Epidemiology of Diabetes Interventions and Complications (EDIC) study (Writing Team for the Diabetes Control and Complications Trial/Epidemiology of Diabetes Interventions and Complications Research Group [EDIC], 2003). It demonstrated that hypertension was developed in $40 \%$ of the patients in the conventionally treated group compared with $30 \%$ in the group treated with an intensified insulin regimen in year 8 of the EDIC follow-up. These beneficial effects were seen in the context of reduced renal disease consistent with the view that hypertension in DM1 is primarily a manifestation of DN in these subjects. Therefore, it appears likely that hyperglycemia or insulin plays a role in influencing BP in DM1 (Elliott et al.; 2001). Regarding DM2, the combination with hypertension appears to cluster clinically as part of a syndrome involving not only these two conditions but also insulin resistance, dyslipidemia, central obesity, hyperuricemia, and accelerated atherosclerosis (Eckel et al.; 2005; Sowers et al.; 2001; Williams, 1994). The underlying explanation for this cluster of clinical features remains unexplained but insulin resistance has been postulated by many investigators as playing a pivotal role (Isomaa et al.; 2001; Sowers et al.; 2001; Williams, 1994).

Clinical progression of DN can be characterized into 5 phases: 1) hyperfiltration with renal hypertrophy, increased renal plasma flow and glomerular filtration; 2) normoalbuminuria with early renal parenchymal changes of basement membrane thickening and mesangial expansion; 3) microalbuminuria with early hypertension; 4) 
overt proteinuria; and 5) ESRD (Mogensen, 1976). These factors collectively result in cell injury and apoptosis of podocytes, and an accumulation of extracellular matrix proteins in the glomerulus and in the tubule interstitium (Calcutt et al.; 2009; D'Agati \& Schmidt, 2010; Decleves \& Sharma, 2010; Ruggenenti et al.; 2010). In this process, the increasing severity of $\mathrm{DN}$ is rapid when there is progression from normoalbuminuria to macroalbuminuria, a transition which takes about ten years.

Pathogenesis of DN is strongly related to uncontrolled or chronic hyperglycemia, and various mechanisms that lead to pathological changes in the kidney, proteinuria, and decline in renal function seen in DN have been proposed (Calcutt et al.; 2009; Decleves \& Sharma, 2010). Hyperglycemia can lead to the activation of oxidative stress and increased production of reactive oxygen species (ROS), increased formation of advanced glycation endproducts (AGEs), activation of the proinflammatory transcription factor $\mathrm{NF}-\mathrm{kB}$, activation of protein kinase $C$ (PKC), transforming growth factor- $\beta$ (TGF- $\beta$ ), and the renin angiotensin system (RAS) (Calcutt et al.; 2009; D'Agati \& Schmidt, 2010; Decleves \& Sharma, 2010; Ruggenenti et al.; 2010).

Apart from its importance in the regulation of arterial BP, salt balance and cardiovascular homeostasis, RAS is also involved in the control of almost every organ system and cell function. Recent advances in cellular and molecular biology, as well as cardiovascular and renal physiology, have provided a larger understanding of RAS involvement in many physiologic and pathophysiologic mechanisms and attesting to its importance in regulating the internal environment is the fact that overactivity of RAS can lead to arterial hypertension, congestive heart failure, and renal insufficiency (Kobori et al.; 2007; Navar et al.; 2011a; Navar et al.; 2011b; Ferrario, 2011; Unger et al.; 1998).

The RAS in diabetes has been studied in detail, including an assessment of the various components of this pathway in the kidney (Ferrario et al.; 2004; Ferrario \& Varagic, 2010; Navar et al.; 2011a; Wehbi et al.; 2001; Zipelmann et al.; 2000). The system has been strongly implicated in the pathophysiology of diabetic renal disease on the basis of its ability to promote tissue remodeling (proliferation, hypertrophy and differentiation) and extracellular matrix remodeling repair and/or fibrosis (Hayden et al.; 2011) and of the therapeutic ability of angiotensin I-converting enzyme inhibitors (ACEi) and AT1 receptor blockers (ARB) to decrease microalbuminuria and the progression of DN to ESRD (Brenner et al.; 2001; Chan et al.; 2000; Heart Outcomes Prevention Evaluation [HOPE] Study Investigators; Lewis et al.; 2001; Parving et al.; 2001). Furthermore, it has been postulated that in diabetes there is a role for the RAS in mediating many of the functional effects, such as changes in intraglomerular hemodynamics as well as structural changes in the diabetic kidney at both glomerular and tubulointerstitial levels (Gilbert et al.; 1998). Based on these findings, pharmacologic interventions that inhibit production of angiotensin II (Ang II) or block angiotensin type-1 receptors (AT1R) that target the RAS are considered a cornerstone in the treatment of hypertension in patients with DN (Van Buren \& Toto, 2011).

\section{Circulanting and tissue renin-angiotensin systems}

The RAS is a coordinated hormonal cascade initiated through biosynthesis of angiotensinogen (AGT), produced in the liver, that is cleaved by renin released from renal juxtaglomerular cells of the afferent arteriole. By this enzymatic cleavage, angiotensin I (Ang I) 

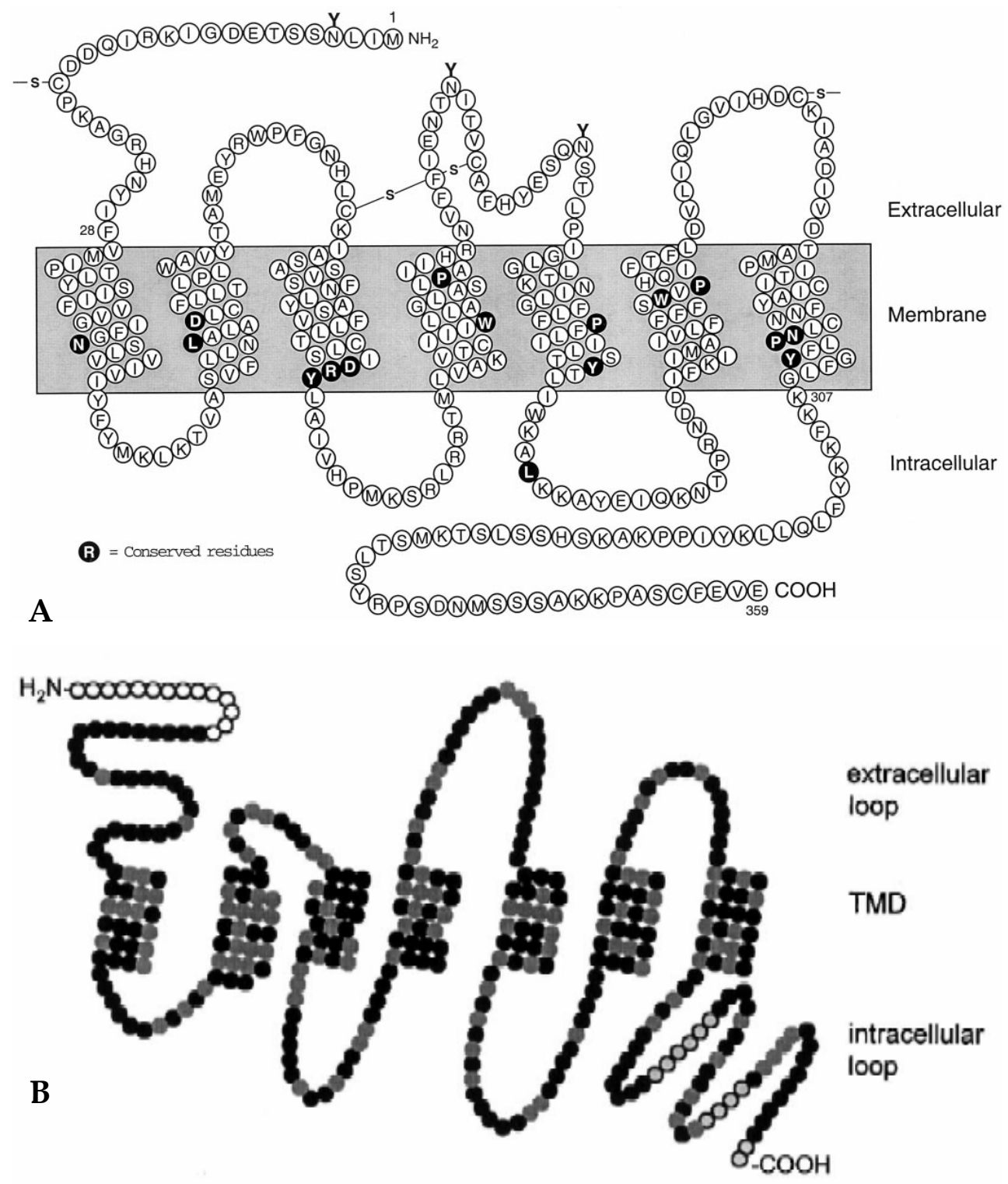

Fig. 1. (A) Secondary structure and consensus sequence of the mammalian angiotensin AT1 receptor. The amino acid residues that are highly conserved among $G$ protein-coupled receptors are indicated in bold letters. The positions of the three extracellular carbohydrate chains, and of the two extracellular disulfide bonds, are also indicated (Adapted from de Gasparo et al.; 2000). (B) Comparison of the AT1 and AT2 receptors, sharing 33- 34\% sequence homology. Grey circles indicate matching pairs of aminoacids. (TMD: transmembrane domain) (Adapted from de Gasparo \& Siragy, 1999). 
is generated, which, in turn is hydrolyzed by angiotensin I-converting enzyme (ACE) to produce Ang II. Over the last years, it has been established that most of the effects of Ang II are mediated through two distinct receptors, angiotensin type-1 receptors (AT1R) and angiotensin type-2 receptors (AT2R), acting antagonistically. AT2R shows only about 33$34 \%$ similarity to AT1R at the amino acid level (Figure 1A and 1B), which suggests that the two receptors derive from different ancestors (Mukoyama et al.; 1993; Kambayashi et al.; 1993; de Gasparo \& Siragy, 1999; Unger \& Sandmann, 2000; de Gasparo et al.; 2000).

Angiotensin actions via AT1R promotes vasoconstriction, inflammation, salt and water reabsorption and oxidative stress (Carey \& Siragy, 2003). AT2R is generally associated with opposite actions to the AT1R, and it has already been shown that its activation induces bradykinin (BK) and nitric oxide formation, leading to natriuresis and vasodilatation. The AT2R is abundant in fetal tissue, decreasing after birth, with low amounts expressed in adult tissue such as kidney, adrenal and brain (Touys \& Schiffrin, 2000; Carey \& Padia, 2008; Rosivall, 2009) (Table 1A and 1B).

- $\quad$ Always expressed (Unger \& Sandmann, 2000)

- Increased arterial pressure (Navar et al.; 2002)

- $\quad$ Aldosterone synthesis and secretion (Allen et al.; 2000; Navar et al.; 2002)

- $\quad$ Release of vasopressine (Unger \& Sandmann, 2000)

- $\quad$ Decreased renal blood flow (Navar et al.; 2002)

- $\quad$ Renin secretion (Navar et al.; 2002)

- Cardiac contractility and hypertrophy (Allen et al.; 2000)

- Vascular smooth muscle cells proliferation (Touyz \& Schiffrin, 2000)

- Mediates vasoconstriction, modulation of central sympathetic nervous system activity (Allen et al.; 2000; Unger \& Sandmann, 2000)

- $\quad$ Mediates cell growth (Unger \& Sandmann, 2000)

- Extracellular matrix formation (Touyz \& Schiffrin, 2000)

Table 1A. Functions of AT1R

- $\quad$ Expressed during stress or injury (Unger \& Sandmann, 2000)

- $\quad$ Fetal tissue development (Nakajima et al.; 1995; Stoll \& Unger, 2001)

- Left ventricular hypertrophy (Senbonmatsu et al.; 2003)

- Mediates vasodilation (Unger \& Sandmann, 2000)

- Neuronal regeneration (Stoll \& Unger, 2001)

- Mediates cell differentiation (Unger \& Sandmann, 2000)

- Inhibits cell growth (antiproliferation) (Unger \& Sandmann, 2000)

- Cellular differentiation (Yamada et al.; 1999)

- Mediates tissue regeneration, apoptosis (Matsubara, 1998; Stoll \& Unger, 2001; Unger \& Sandmann, 2000)

- Modulation of extracellular matrix (Matsubara, 1998)

Table 1B. Functions of AT2R

The classical view of RAS cascade has been increasingly challenged with the discovery of new components such as the angiotensin converting enzyme 2 (ACE2). This enzyme with homology to ACE, is expressed in several tissues, including heart and kidney consistent with a 
role for this enzyme in renal and cardiovascular physiology (Burrell et al.; 2004; Crackower et al.; 2002; Danilczyk et al.; 2003; Donoghue et al.; 2000; Harmer et al.; 2002; Tipnis et al.; 2000). Both isoforms of ACE are type-I transmembrane glycoproteins with an extracellular aminoterminal ectodomain and short intracellular cytoplasmic tail (Figure 2). This membrane localization is ideally positioned it to hydrolyse peptides in the extracellular milieu.

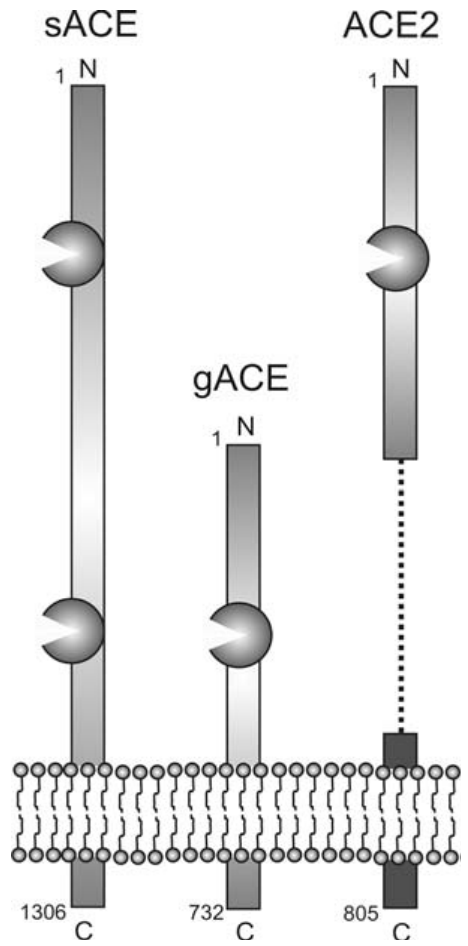

Fig. 2. Membrane topology and homology between ACE and ACE2. The ACE isoforms somatic ACE (sACE) and germinal ACE (gACE) and ACE2, are type I transmembrane proteins with an intracellular C-terminal domain and an extracellular $\mathrm{N}$-terminal domain. In the case of the ACE isoforms and ACE2, the N-terminal extracellular domains contain HEMGH zinc-dependent catalytic domains (denoted as 'Pacman' symbols); two in ACE and one in both gACE and ACE2. Germinal ACE is entirely homologous to the C-terminal domain of sACE. ACE2 shares homology in its ectodomain with the N-terminal domain of sACE but has no homology with its C-terminal cytoplasmic domain (Adaptated from Lambert et al.; 2010).

ACE2 presents a single catalytic site and catalyzes the cleavage of Ang I to Ang 1-9, which can be further cleaved by ACE to Ang 1-7 (Burrell et al.; 2004; Donoghue et al.; 2000). Furthermore, Ang II can be converted directly by ACE2 to Ang 1-7. Ang 1-7 has been shown to exert vasodilatory properties and to antagonize the vasoconstriction mediated by Ang II, thereby contributing to the balance of vasodilators and vasoconstrictors generated by the various components of the RAS (Almeida et al.; 2000; Moriguchi et al.; 1995; Ferrario, 2006; Santos \& Ferreira, 2007). 
Another relevant change in our understanding of the classical endocrine RAS was the description of all components of the system in several tissues, including kidney, heart, brain, pancreas, adrenal, reproductive aparatus, retina, liver, gastrointestinal tract, lung and adipocytes, leading to the identification of new roles for angiotensins as paracrine and autocrine/intracrine function (Bataller et al.; 2003; Danser \& Schalekamp, 1996; Lavoie \& Sigmund, 2003; Navar et al.; 1994; Paul et al.; 2006; Ribeiro-Oliveira Jr et al.; 2008; Senanayake et al.; 2007; Tikellis et al.; 2003). RAS tissue appears to be regulated independently of the systemic one, and has been shown to contribute to a great number of homeostatic pathways, including cellular growth, vascular proliferation, extracellular formation and apoptosis (Paul et al.; 2006), via its specific receptors, such as AT1R, AT2R, prorenin/renin [(P)RR], Mas and also Ang III and IV receptors (Figure 3) (Nguyen et al. 2002; Santos et al.; 2003).

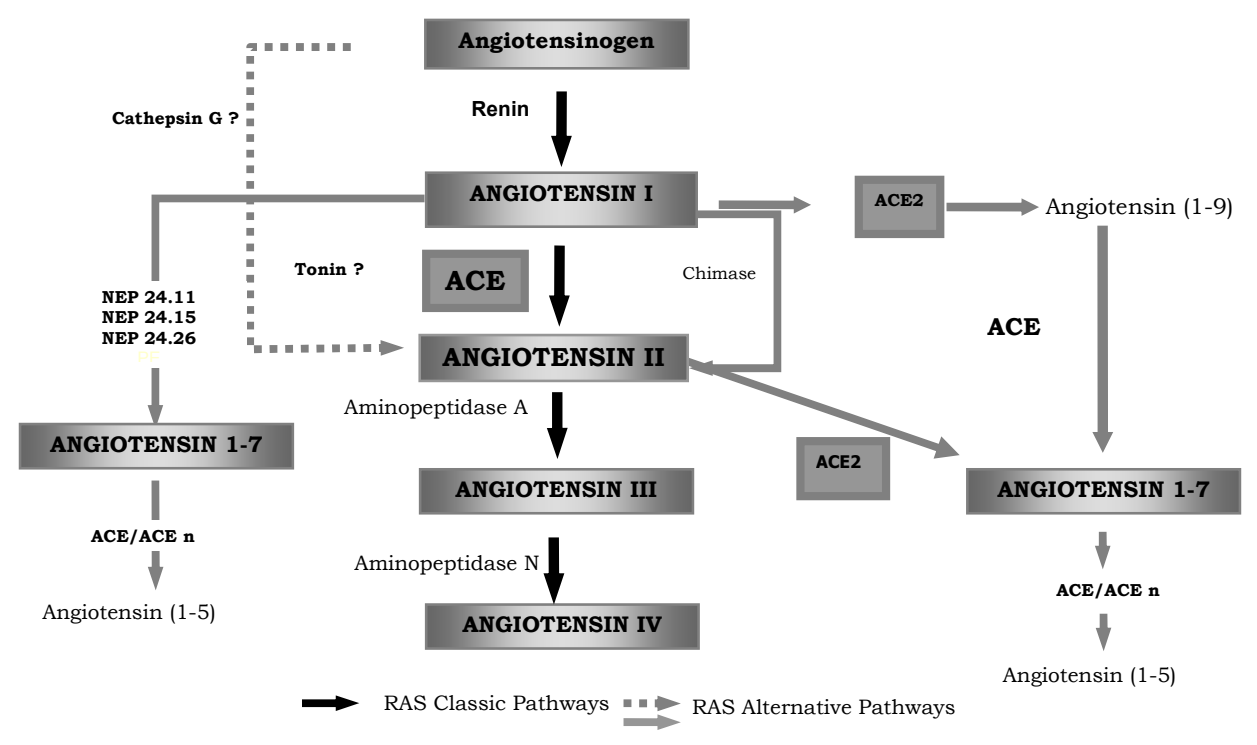

Fig. 3. Schematic representation of RAS. ACE, ACE 2, Neutral endopeptidase (NEP), N-domain ACE (ACEn).

\section{The intrarenal RAS}

\subsection{Angiotensinogen}

AGT is a glycoprotein produced in the liver, kidney, heart, vessels and adipose tissue, which circulates as an inactive protein. AGT is hydrolyzed by renin to generate Ang I, and both the peptide and renin are considered the rate-limiting steps in the formation of Ang II. Studies with mice harboring the gene for human AGT fused to the kidney-specific androgen regulated protein promoter demonstrated that AGT mRNA and the protein were localized in the proximal tubule cells, and urinary AGT was described as a product secreted by the 
proximal tubules and excreted in urine (Ding et al.; 1997; Kobori et al.; 2003). AGT synthesis is stimulated by inflammation, insulin, estrogen, glucorticoids (Kobori et al.; 2007; PrietoCarrasquero et al.; 2004), and Kobori et al. (2001) described that Ang II can stimulate renal AGT mRNA and AGT protein synthesis, amplifying the activity of the intrarenal RAS (Kobori et al.; 2001).

\subsection{Renin and prorenin}

Renin is an aspartyl protease produced by the juxtaglomerular apparatus of the kidney. Its active form contains 339 amino acid residues after proteolytic cleavage at the N-terminus of prorenin, and in the circulation prorenin concentration is higher than that of renin. The activation of prorenin may occur by proteolytic or non proteolytic pathtways, both being able to generate Ang I from AGT. Circulating active renin and prorenin are originated mainly from the kidney, but other tissues are able to secrete both enzymes into the circulation, and therefore renin was also detected in urine suggesting its tubular formation, especially in the collecting duct (Prescott et al.; 2002; Prieto-Carrasquero et al.; 2004). As renin was also described in the collecting ducts, authors observed that Ang II is unable to inhibit renin secretion in this segment, the opposite to that which has been described in the juxtaglomerular apparatus (Kang et al.; 2008; Prieto-Carrasquero et al.; 2004; Rosivall, 2009).

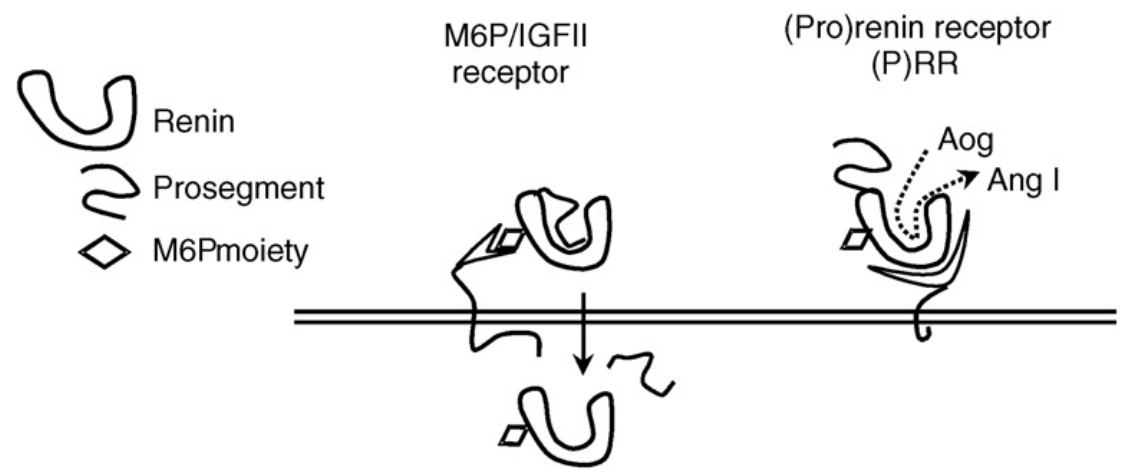

\begin{tabular}{|c|c|c|}
\hline Binding of renin and prorenin: & via $\mathrm{M} 6 \mathrm{P}$ residues & Specific, $\mathrm{K}_{D} \mathrm{nM}$ \\
\hline Angiotensin I generation: & Intracellular & Cell surface \\
\hline Activation of prorenin: & Proteolytic & Non-proteolytic \\
\hline Signalling: & $\begin{array}{c}\text { No, } \\
\text { Clearance receptor }\end{array}$ & $\begin{array}{c}\text { MEK } 1 / 2, \text { ERK1/2 } \\
\text { P38, HSP70 }\end{array}$ \\
\hline Cellular effects: & None & $\begin{array}{c}\text { Up-regulation of TGF } \beta, \text { PAI1, } \\
\text { collagens, fibronectin } \\
\text { expression, } \\
\text { Mesangial cells proliferation }\end{array}$ \\
\hline
\end{tabular}

Fig. 4. Principal characteristics of the two receptors for renin and prorenin, the mannose-6phosphate receptor and the (pro)renin receptor $((\mathrm{P}) \mathrm{RR})$ (Adapted from Nguyen \& Contrepas, 2008). 
The specific receptor for renin and for its inactive proenzyme form, prorenin, was cloned in 2002 and called (P)RR for (pro)renin receptor. The PRR gene is named ATP6ap2/PRR because a truncated form of $(\mathrm{P}) \mathrm{RR}$ was previously described to coprecipitate with the vacuolar H+-proton adenosine triphosphatase (V-ATPase) (Nguyen et al.; 2002). The (P)RR is a single trans-membrane domain receptor that acts as co-factor for renin and prorenin by increasing their enzymatic activity on the cell-surface and mediating an intracellular signaling. It activates the mitogen activated protein kinases ERK1/2 cascade leading to cell proliferation and to up-regulation of profibrotic gene expression (Nguyen, 2011).

Two $(\mathrm{P}) \mathrm{RRs}$ have been characterized to date, the functional receptor specific for renin and prorenin (Nguyen et al.; 2002) and the ubiquitous mannose-6-phosphate receptor (M6P-R) which is admitted to be a clearance receptor (Saris et al.; 2001) (Figure 4). It is known that the binding of renin with $(\mathrm{P}) \mathrm{RR}$ increases its catalytic efficiency upon its substrate, a phenomena that may be implicated in target-organ lesion in the kidney and the development of DN (Ichihara et al.; 2006; Nguyen et al.; 2002). On the other hand, increases in prorenin concentration may decrease the (P)RR expression that can act as a negative feedback (Ichihara et al.; 2006; Nguyen et al.; 2002; Staessen et al.; 2006). Moreover, studies in genetically modified animals overexpressing $(\mathrm{P}) \mathrm{RR}$ a role for $(\mathrm{P}) \mathrm{RR}$ cardiovascular and renal pathologies since rats overexpressing (P)RR in vascular smooth-muscle cells develop high BP and those with an ubiquitous overexpression of (P)RR have glomerulosclerosis and proteinuria (Nguyen \& Contrepas, 2008).

\subsection{Angiotensin I-converting enzyme (ACE)}

ACE is an ectoenzyme located in many vascular beds and also on cell surface of mesangial, proximal and collecting duct cells in the kidney and was described as a dipeptidyl carboxypeptidase (Camargo de Andrade et al.; 2006; Redublo Quinto et al.; 2008). It catalyzes the conversion of the decapeptide Ang I to the octapeptide Ang II, which is a potent vasoconstrictor, and in addition inactivates the vasodilator BK (Erdos, 1976).

The ACE gene encodes two enzymes: a somatic isozyme (150-180 kDa) and a germinal or testicular isozyme isozyme $(90-100 \mathrm{kDa})$ identical to the C-terminal portion of endothelial ACE, only expressed in sperm (Hall, 2003; Lattion et al.; 1989). A soluble isoform of ACE, which is derived from the membrane bound isoform by the action of secretases, is also present in serum and other body fluids such as urine (Casarini et al.; 1995; Casarini et al.; 2001; Xiao et al.; 2004). ACE homologs have also been found in other animal species, including chimpanzee, cow, rabbit, mouse, chicken, goldfish, electric eel, house fly, mosquito, horn fly, silk worm, Drosophila melanogaster and Caenorhabditis elegans, and in the bacteria Xanthomonas spp. and Shewanella oneidensis (Corvol \& Williams, 1998; Riordan, 2003). The cDNA of one form of D. melanogaster ACE (termed AnCE) encodes a protein of 615 amino acids that have a high degree of similarity to both domains of human sACE, indicating that the D. melanogaster protein is a single-domain enzyme (Williams et al.; 1996; Riordan, 2003) (Figure 5A). It contains a signal peptide but no carboxy-terminal membrane-anchoring hydrophobic sequence. A second ACE-related gene product, termed Acer, has also been identified in D. melanogaster. Selective inhibition by phosphinic peptides (containing -PO2-CH2- links instead of -CO-NH- links) indicates that Acer has active site features characteristic of the $\mathrm{N}$ - domain of sACE (Riordan, 2003). 
ACE presents two distinct catalytic domains, called N- and C-terminus (Wei et al.; 1991) (Figure $5 \mathrm{~A}$ and $\mathrm{B}$ ), and both sites hydrolyze Ang I. However, the N-domain has two specific physiological substratum, Ang 1-7 and N-acetyl-Seryl-Aspartyl-Lysyl-Proline, a hematopoietic peptide (Jaspard et al.; 1993; Rousseau et al.; 1995). ACE is distributed along human and rat kidney, and has already been described in glomeruli, mesangial cells and also in proximal and collecting duct cells (Camargo de Andrade et al.; 2006; Redublo Quinto et al.; 2008). Casarini et al. (1995 and 2001) observed two N-domain ACE isoforms (nACE)

(A)

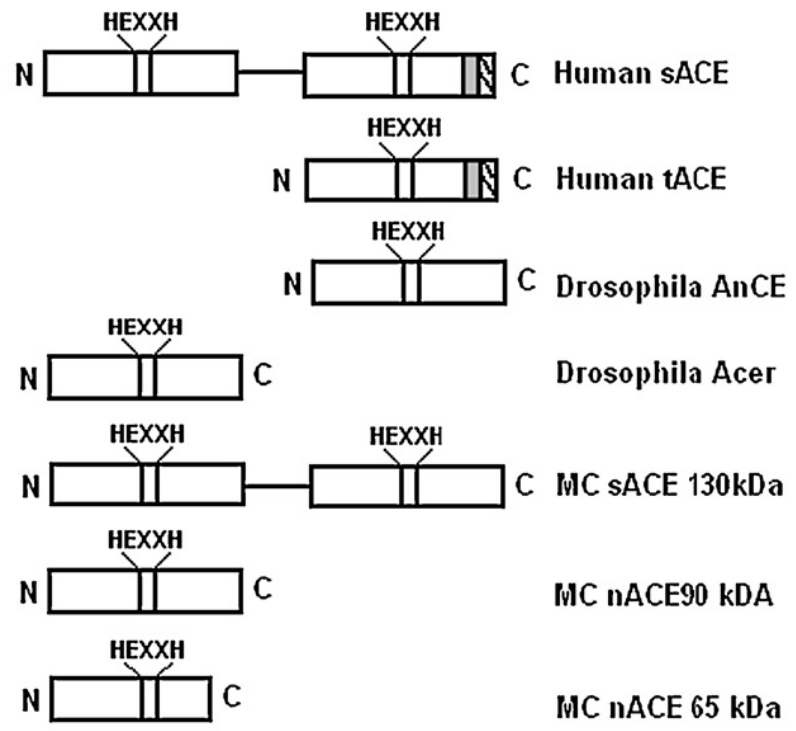

(B)
ACE $65 \mathrm{kDa}$
Somatic
GYLVDQXRXGVFS
440 450 460 470 480

\section{ACE $90 \mathrm{kDa}$} Somatic

\section{YGLDALDAQPULKYFOPYTQWLLEQNOQNGEVL XPEYQXHPP}

EVLGXPEYQXHPP

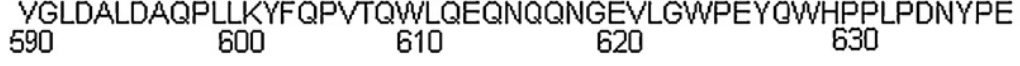

Fig. 5. Schematic representation of primary structure of several members of the ACE protein family. (A) Location of the active-site-zinc-binding motifs are indicated by HEXXH; transmembrane domains are in black. The sequence of testicular ACE (tACE) is identical to that of the C-domain of the sACE, except for its first 36 amino acids. Human tACE and sACE have the same carboxyl-terminal transmembrane and cytosolic sequence. Drosophila ACEs, cDNA of one form of D. melanogaster ACE (termed AnCE) and a second ACErelated gene product (termed Acer) lack a membrane-anchoring sequence. Dimensions are not to scale. N, amino terminus; C, carboxyl terminus (Adapted from Riordan, 2003). (B) The C-terminal alignment of $65 \mathrm{kDa} \mathrm{nACE}$ with rat ACE ended at Ser482. The same analysis for $90 \mathrm{kDa}$ nACE evidenciated that the enzyme finished at Pro629 amino acid after their alignment with rat ACE. Both structures are similar for urine, tissue and mesangial cells (Adapted from de Andrade et al.; 2010). 
with molecular weight of 190 and $65 \mathrm{kDa}$ in the urine of healthy subjects, and two isoforms of 90 and $65 \mathrm{kDa}$, both nACE, in the urine of hypertensive patients (Casarini et al.; 1995, 2001). The same nACE enzymes were obtained by Marques et al. (2003) in the urine of Wistar-Kyoto and Spontaneously Hypertensive rats (SHR), and by Ronchi et al. (2005) in different tissues of SHR, suggesting that the $90 / 80 \mathrm{kDa}$ ACE could be a possible biological marker of hypertension (Marques et al.; 2003; Ronchi et al.; 2005). Moreover, Deddish et al. (1994) described an active soluble form of nACE in human ileal fluid, with a molecular mass of 108 $\mathrm{kDa}$, thereby differing from the enzymes described in human urine (Deddish et al.; 1994).

Apart from the classic actions of ACE, several groups have recently demonstrated that ACE presents novel actions, mainly related to cell signaling. As demonstrated by Kolstedt et al (2004), ACE also functions as a signal transduction molecule and binding of ACE substrates or inhibitors to the enzyme initiates a cascade of events, including the phosphorylation of its Ser1270 residue, increasing ACE and COX2 synthesis. Moreover, using in vitro models such as Chinese hamster ovary and melanoma cells, it was demonstrated that Ang II can also interact with ACE evoking calcium signaling and promoting an increase in the generation of ROS (Guimaraes et al.; 2011; Kohlstedt et al.; 2004).

\subsection{ACE2}

ACE2 is a new member of RAS, homologue of ACE, which acts as a monocarboxipeptidase. The enzyme consists of 805 amino acids and is a type I transmembrane glycoprotein with a single extracellular catalytic domain (Donoghue et al.; 2000; Tipnis et al.; 2000). Unlike somatic ACE, ACE2 removes a single C-terminal Leu residue from Ang I to generate Ang 19, a peptide with unknown function. Although ACE2 was described originally for its ability to generate Ang 1-9 from Ang I (Donoghue et al.; 2000), it also degrades Ang II to the biologically active peptide Ang 1-7 (Burrell L et al, ,2004; Vickers et al.; 2002). In vitro studies showed that the catalytic efficiency of ACE2 for Ang II is 400-fold greater than for Ang I (Vickers et al.; 2002), indicating that the major role for ACE2 is the convertion of Ang II to Ang 1-7.

The human ACE2 gene has been cloned and mapped to the $\mathrm{X}$ chromosome (Crackower et al.; 2002). This enzyme exists as a membrane-bound protein in the lungs, stomach, spleen, intestine, bone-marrow, kidney, liver, brain (Gembardt et al.; 2005) and the heart and is not inhibited by ACE inhibitors (Ribeiro-Oliveira Jr et al.; 2008). ACE2 is abundantly expressed in renal epithelial cells including proximal tubular cells (Danilczyk \& Penninger, 2006; Donoghue et al.; 2000; Shaltout, et al.; 2007), and in the pancreas, ACE2 was found to be localized to acini and islets following a similar distribution to that of ACE (Tikellis et al.; 2004).

Several studies support a counter-regulatory role for Ang 1-7 by opposing many AT1Rmediated actions, especially regarding vasoconstriction and cellular proliferation (Ferrario, 2006, Santos et al.; 2005). Thus, Ang 1-7 has become a key component of the RAS system due to its beneficial effects in the cardiovascular system. Although the pathophysiological significance of ACE2 in renal injury remains to be established, emerging evidence suggests that ACE2 deficiency leads to increases in intrarenal Ang II levels (Ribeiro Oliveira Jr et al.; 2008; Ferrario, 2006; Oudit et al.; 2010; Wolf \& Ritz, 2005; Ye et al.; 2006). Thus, recently ACE2 has also been proposed as an acute biomarker of renal disease, considering that upregulation of ACE2, and the subsequent increase in Ang 1-7 levels, may be a compensatory response to 
protect against tissue injury. In fact, in response to chronic injury, ACE2 protein levels are significantly downregulated in the kidneys of hypertensive (Crackower et al.; 2002), diabetic (Tikellis et al.; 2003) and pregnant rats (Brosnihan et al.; 2004; Brosnihan et al.; 2003) suggesting the potential role of the enzyme as a kidney disease biomarker.

\subsection{Angiotensins and receptors}

BP is modulated by changes in plasma concentrations of Ang II, due to an increase in total peripheral resistance to maintain arterial BP in face of an acute hypontesive modification as blood loss and/or vasodilation. Ang II causes a slow pressor response to stabilize the arterial BP mediated by a renal response, through mechanisms that include a direct effect to increase sodium reabsortion in proximal tubules, release of aldosterone from adrenal and altered renal hemodynamics (Carey et al.; 2000), including increased capillary glomerular pressure, hyperfiltration and proteinuria (Navar \& Harrison-Bernard, 2000). Ang II also has important effects on cardiovascular system, stimulating migration, proliferation, hypertrophy, increased production of growth factors and extracellular matrix proteins such as collagen, fibronectin (Carey et al.; 2000).

Angiotensins have their actions exerted through AT1R and AT2R interaction, and Ang II, but not Ang I, has affinity to both of them. The actions of AT1R include vasoconstriction, aldosterone secretion, tubular sodium retention, release of vasopressin, increased sympathetic nervous activity and increased thirst. In the long term, actions of AT1R also include cell growth, organ hypertrophy, inflammation, remodeling and erythropoietic stimulation. On the other hand, AT2R mediates effects that are opposed to the actions of AT1R, and it has already been shown that AT2R is upregulated in response to tissue injury, suggesting its important role in the pathophysiology of several diseases (Hunyady \& Catt, 2006).

Several studies demonstrated AT1R and AT2R expression in renal tissue, and their role in the development of renal disease. A study with SHR after 32 weeks of STZ-induced DM, suggested that hypertension, increased albuminuria and renal injury were resulted from the reduction of expression of enconding genes for AT1R, and treatment with ibersatan prevented the down regulation of the AT1R receptor, with no effect on AT2R expression (Bonnet et al.; 2002). Moreover, Velloso et al. (2006) also demonstrated an interaction between RAS and the insulin signaling pathways, through AT1R as a result of treatment with ARB (Velloso et al.; 2006).

Changes in the population of renal ATR can be involved in DN. Diabetes reduced gene and protein expression of AT1R but not AT2R in the kidneys of SHR rats, without changes in Wistar-Kyoto (WKY) strain. This reduction is supposed to be a protective mechanism against the intrarenal RAS activation by diabetes, and this effect was cancelled by the ARB ibersatan (Bonnet et al., 2002). Also, the cross-talk between AT1R and insulin receptor signaling pathways is related to the association between diabetes and hypertension, and may contribute to tissue damage (Velloso et al. 2006) induced by these pathologies.

\section{RAS and diabetes}

The activation of renal RAS, and the subsequent generation of Ang II, is the primary etiologic event in the development of hypertension in people with DM. Subsequently, the 
increase of Ang II is responsible for the development of DN, a major cause of ESRD, via several hemodynamic, tubular and growth-promoting actions, as evidenced by the fact that blockade of this system has a beneficial effect on the kidney (Lewis et al.; 1993, 2001).

RAS inhibition is important to prevent renal and cardiovascular complications of both DM1 and DM2, through mechanisms that include improvement in endothelial fuction (Mukai et al.; 2002), decrease in inflammatory response (Mervaala et al.; 1999), increase in BK and Ang 1-7 levels (Maia et al.; 2004). The initial studies with RAS inhibition in people with DN demonstrated that there was an effect beyond BP lowering. When compared with conventional antihypertensive therapy, those who received RAS blockade consistently had greater improvement in DN despite presenting similar BP control, through effects of RAS blockade on insulin resistance and glucose homeostasis (Gillespie et al.; 2005; Lewis et al.; 1993; Ravid et al.; 1998). Thus, it was suggested a role for ACE in mediating renal injury by increasing local Ang II formation, prevented by both ACEi and ARB in the kidney. ACEi reduce the production of Ang II, and decrease degradation of endothelial BK, resulting in vasodilatation by stimulating nitric oxide and prostacyclin production and $\mathrm{BP}$ reduction. Moreover, ACEi have been shown to decrease the rate of progression of diabetic and nondiabetic nephropathies, and improve insulin sensitivity, allowing better insulin action in patients with DM2 (Lewis et al.; 1993; Yusuf et al.; 2000). On the other hand, ARB have also been shown to decrease the risk of stroke in patients with hypertension and reduce the rate of progression of DN (Lewis et al.; 1993). ABR prevent the binding of Ang II to AT1R, leading to accumulation of Ang II, which in turn is converted to Ang 1-7 and increases the levels of this vasodilator peptide (Barra et al.; 2009; Ferrari, 2005; Maia et al.; 2004).

Several studies have demonstrated that activity of circulating (systemic) RAS is normal or suppressed in DM, as reflected by measurements of plasma renin activity and Ang II concentrations, while local renal tissue RAS (tRAS) has already been shown to be activated on cell culture, in response to high glucose exposure, and also on spontaneously or induced diabetic animals (Carey \& Siragy.; 2003b).

During the activation of tRAS in DM, Ang II activates NADPH oxidase enzyme which contributes to the generation of ROS. This process may result from over production of precursors to reactive oxygen radicals and or decreased efficiency of inhibitory and scavenger systems. In DM, the additional AT1R activation results in a vicious cycle of ROS production which contributes to organ damage (Hayden et al.; 2011). The mechanisms that contribute to increased oxidative stress in diabetes may include not only increased non enzymatic glycosylation (glycation) and autoxidative glycosylation (Baynes, 1991), but it is also related to several abnormalities, including hyperglycemia, insulin resistance, hyperinsulinemia and dyslipidemia, each of which contributes to mitochondrial superoxide overproduction in endothelial cells in large and small vessels as well as the myocardium.

The pathophysiological mechanism that underlies diabetic complications could be explained by increased production of ROS via the polyol pathway flux, increased formation of advanced glycation end products, increased expression of the receptor for AGEs, activation of protein kinase $C$ isoforms and overactivity of the hexosamine pathway. Furthermore, the effects of oxidative stress in individuals with DM2 are compounded by the inactivation of two critical anti-atherosclerotic enzymes: endothelial nitric oxide synthase and prostacyclin synthase (Folli et al.; 2011). 
Increased AGT expression, in response to high glucose exposure, was also described to be involved in the development of $\mathrm{DN}$, in vitro (Hsieh et al, 2003) and in vivo. Using an in vitro model, Vidotti et al. (2004) demonstrated that high glucose exposure increased Ang II generation, decreased prorenin secretion and induced an increase in intracellular renin activity of mesangial cells. In response to $72 \mathrm{~h}$ of high glucose exposure, there was an increase in mRNA levels for AGT and ACE, while 24h of the stimulus increased mRNA levels of ACE, prorenin and cathepsin B. In this study, increased generation of Ang II, induced by high glucose exposure, was shown to be dependent on at least three factors: a time-dependent stimulation of (pro)renin gene transcription, a reduction in prorenin enzyme secretion, and an increased rate of conversion of prorenin to active renin, probably mediated by cathepsin B. Moreover, the consistent upregulation of ACE mRNA suggests that, along with renin, ACE is directly involved in the increased mesangial Ang II generation induced by high glucose (Vidotti et al.; 2004).

In the kidney of streptozotocin (STZ)-induced diabetic animals, an increase in intrarenal AGT mRNA is attributed to the proximal tubule, and it seems to be mediated by glucose response element located in the AGT promoter (Zimpelman et al.; 2000). Studies with Zucker obese rat, a model of DM2 with nephropathy and hypertension, is also associated with increased activation of RAS, as demonstrated by an increase in intrarenal Ang II generation, which was prevented by treatment with ACEi (Sharma et al.; 2006). Using Nonobese diabetic model (NOD) (Makino et al.; 1980), our group demonstrated that diabetes onset increases ACE activity and expression and decreases ACE2 expression in kidney, suggesting that the higher renal ACE/ACE2 ratio may contribute to renal injury leading to overt nephropathy (Colucci et al.; 2011).

Ronchi et al. (2007) studied the association between sACE with $136 \mathrm{kDa}$ and nACE with 69 $\mathrm{kDa}$ from Wistar (W) rat tissue with DM. The authors analysed three groups: control (CT), insulin treated diabetic (DT) and untreated (D). In D group, urine ACE activity increased for both substrates, Hippuryl-His-Leu and Z-Phe-His-Leu, that distinguished nACE from somatic ACE when compared with CT and DT, despite the decreased activity in renal tissues. Immunostaining of renal tissue demonstrated that ACE is more strongly expressed in the proximal tubule of D than in the same nephron portion in the other groups. Ang I increased in the renal tissue of D and DT groups, but Ang II levels decreased in the D and DT groups when compared to the control. Ang 1-7 was detected in all studied groups with low levels in DT. These findings indicate that Ang I increase and Ang II decrease, as a result of renin and NEP simultaneous activation, increasing Ang 1-7. Since Ang 1-7 can counterbalance Ang II effects, this modulation of angiotensin peptides has a protective role against renal damage in DM (Ronchi et al., 2007).

Few studies were described using animal models with genetic alterations in the RAS in DN. Studies have suggested associations between incidence of DN and a variety of genetic polymorphisms. An association was identified between nephropathy in DM1 and the D allele of an insertion/deletion (I/D) polymorphism in intron 16 of ACE gene. Huang et al.; (2001) described that the induction of diabetes by SZT was not affected by ACE gene copy number. The authors compared the changes with the time of BP of one, two and three-copy mice with the pressures of untreated controls. The BPs of untreated mice were not affected by ACE gene copy, however the $\mathrm{BP}$ of the three-copy diabetic mice with genetically higher ACE activity increased with time, and 12 weeks after induction of diabetes were 10-20 mmHg higher than the BPs of the one and two copy diabetic mice (Huang et al.; 2001). 
Regarding ACE2, differences in renal enzyme levels have been detected in hypertensive humans when compared with controls (Van Buren \& Toto, 2011). Wong et al. (2002) have shown that pharmacological inhibition of ACE2 and genetic ablation in different rodent of models of diabetes, increased albuminuria and glomerular lesions. Furthermore, animals with STZ-induced DN have decreased renal expression of ACE2 (Tikellis et al.; 2003). In humans, biopsies from patients with DN showed a decrease in glomerular expression of ACE2, suggesting that a therapy increasing the activity of this enzyme can help in the future in the treatment of diabetic kidney disease (Wong et al.; 2007).

Aldosterone has been implicated in DM complications. Sato et al (2003) in a study in patients with DM2 described that patients with aldosterone escape of $40 \%$ have higher albumin excretion than those without. Treating these patients with spironolactone associated to $\mathrm{ACEi}$, the authors detected reduction in urinary albumin excretion over a 24week period. They conclude that RAS activation in DN could be related to an aldosteronemediated increase in disease progression. (Sato et al.; 2003).

\section{Conclusion}

We reviewed the physiology of the RAS in DM and hypertension, highlighting the importance of this system in diabetic nephropathy. The RAS is up or down regulated in the kidney and Table 2 summarizes the role of components of the RAS in diabetic nephropathy. Figure 6 presents our understanding of the intrarenal RAS in diabetic nephropathy. Increased Ang II is responsible for both intrarenal insulin resistence and renal injury, as well as, decrease AT2R expression might contribute to accelerated renal injury (Carey and Siragy, 2003b). In addition to controling blood pressure, we evidenciated the importance of ACEi and ARB in protecting the kidney against injury. The newly discovered components of RAS, such as renin receptor, ACE2, Ang IV and also aliskeren, the renin inhibitor, represent that

\begin{tabular}{|c|c|}
\hline Description & References \\
\hline 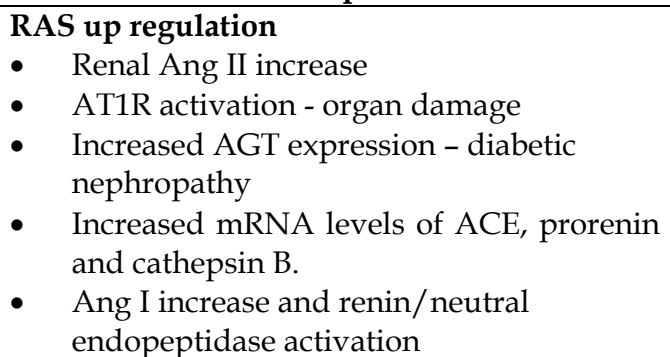 & $\begin{array}{l}\text { Lewis et al., 1993, 2001; Zimpelman et } \\
\text { al., } 2000 \\
\text { Hayden et al.., } 2011 . \\
\text { Hsieh et al, } 2003 . \\
\text { Vidotti et al., } 2004 . \\
\text { Ronchi et al., 2007. }\end{array}$ \\
\hline $\begin{array}{l}\text { RAS down regulation } \\
\text { - } \quad \text { ACE inhibition - increase in BK and Ang } \\
\text { 1-7, control of blood pressure } \\
\text { - } \quad \text { ACE inhibition, improve insulin } \\
\text { - } \quad \text { ACnsitivity } \\
\text { - } \quad \text { ACE2 decrease } \\
\text { and glomerular lesions }\end{array}$ & $\begin{array}{l}\text { Maia et al., } 2004 . \\
\text { Lewis et al., 1993; Yusuf et al., } 2000 . \\
\text { Colucci et al., 2011; Wong et al., } 2007 \\
\text { Wong et al.,2002. }\end{array}$ \\
\hline
\end{tabular}

Table 2. RAS is up- or down-regulated in diabetic kidneys 
research is open in this field. New pathways and signaling compounds can be discovered explaining the modulation of the RAS resulting in expression of other genes.

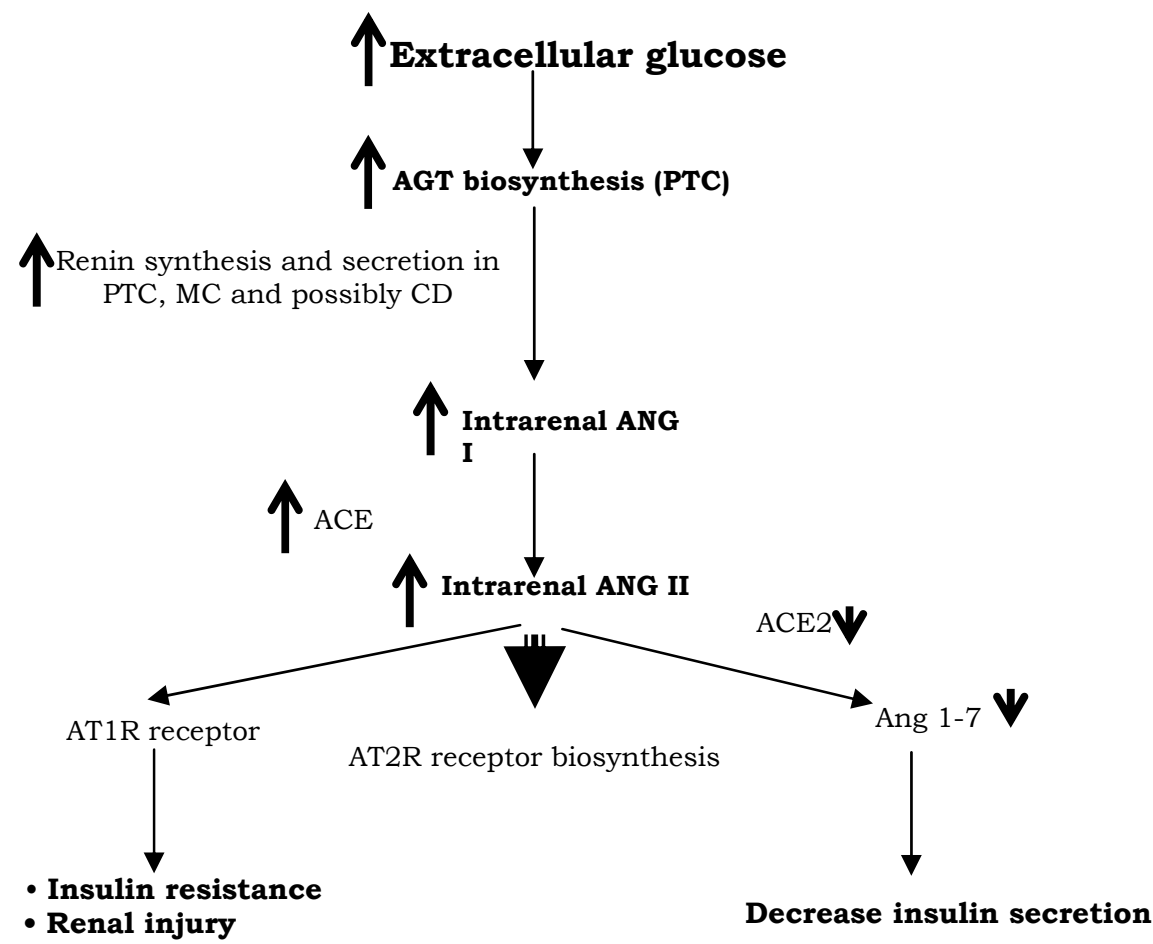

Fig. 6. Pathways through which the intrarenal renin-angiotensin system contributes to diabetic nephropathy based on current evidence. Solid arrows represents biochemical pathways or ligand-receptor interactions. The broken arrow indicates decreased ligandreceptor interaction owing to decreased AT2R synthesis. Abbreviations: ACE, angiotensinconverting enzyme; ACE2, angiotensin-converting enzyme2; AGT, angiotensinogen; ANG, angiotensin; AT1R, angiotensin II receptor; AT2R angiotensin II receptor; MC, glomerular mesangial cell; PTC, proximal tubule cell. Adapted from Carey and Siragy, 2003b.

\section{References}

Allen, A.M.; Zhuo, J.; Mendelsohn, F.A. (2000). Localization and function of angiotensin AT1 receptors. American Journal of Hypertension, Vol. 13, No. (1 Pt 2), (January 2000), pp. 31S-38S, ISSN 0895-7061.

Almeida, A.P.; Frabregas, B.C.; Madureira, M.M.; Santos, R.J.; Campagnole-Santos, M.J. \& Santos, R.A. (2000). Angiotensin-(1-7) potentiates the coronary vasodilatatory effect of bradykinin in the isolated rat heart. Brazilian Journal of Medical and Biological Research, Vol.33, No.6, pp. 709-13, ISSN 0100-879X. 
Astrup, A. \& Finer, N. (2000). Redefining type 2 diabetes: 'diabesity' or 'obesity dependent diabetes mellitus'?. Obesity Reviews, Vol.1, No.2, (October 2000), pp. 57-59, ISSN 1467-7881.

Barra, S.; Vitagliano, A.; Cuomo, V.; Vitagliano, G. \& Gaeta, G. (2009). Vascular and metabolic effects of angiotensin II receptor blockers. Expert Opinion on Pharmacotherapy, Vol.10, No.2, (February 2009), pp. 173-189, ISSN 1465-6566.

Bataller, R.; Sancho-bru, P.; Ginés, P.; Lora, J.M.; Al-garawi, A.; Solé, M.; Colmenero, J.; Nicolás, J.M.; Jiménez, W.; Wich, N.; Gutiérrez-Ramos, J.; Arroyo, V. \& Rodés, J. (2003). Activated human hepatic stellate cells express the renin angiotensin system and synthetize angiotensin II. Gastroenterology, Vol.25, (July 2003), pp. 117-125, 2003, ISSN 0016-5085.

Baynes, J.W. (1991). Role of oxidative stress in development of complications in diabetes. Diabetes, Vol.40, No.4, (April 1991), pp. 405-412, ISSN 0012-1797.

Bonnet, F.; Candido, R.; Carey, R.M.; Casley, D.; Russo, L.M.; Osicka, T.M.; Cooper, M.E. \& Cao, Z. (2002). Renal expression of angiotensin receptors in long-term diabetes and the effects of angiotensin type 1 receptor blockade. Journal of Hypertension Vol.20, No.8, (August 2002), pp. 1615-1624, ISSN 0263-6352.

Brenner, B.M.; Cooper, M.E.; de Zeeuw, D.; Keane, W.F.; Mitch, W.E.; Parving, H.H, Remuzzi, G.; Snapinn, S.M.; Zhang, Z.; Shahinfar, S.\& RENAAL Study Investigators. (2001). Effects of losartan on renal and cardiovascular outcomes in patients with type 2 diabetes mellitus and nephropathy. The New England Journal of Medicine, Vol. 345, No.12, (September 2001), pp. 861-869, ISSN 0028-4793

Brosnihan, K.B.; Neves, L.A.; Anton, L.; Joyner, J.; Valdes, G .\& Merrill, D.C. (2004) Enhanced expression of Ang-(1-7) during pregnancy. Brazilian Journal of Medical and Biological Research, Vol.37, No.8, (August 2004), pp. 1255-1262, ISSN0100-879X.

Brosnihan, K.B.; Neves, L.A.; Joyner, J. Averill, D.B.; Chappell, M.C.; Sarao, R.; Penninger, J. \& Ferrario, C.M. (2003). Enhanced renal immunocytochemical expression of ANG(1-7) and ACE2 during pregnancy. Hypertension, Vol42, No.4, (October 2003), pp. 749-53), ISSN 0194-911X.

Burrell, L.M.; Johnston, C.I.; Tikellis, C. \& Cooper, M.E. (2004). ACE2, a new regulator of the renin-angiotensin system. Trends in Endocrinology and Metabolism, Vol.15, No.4, (May-June 2004), pp. 166-169, ISSN 1043-2760.

Calcutt, N.A.; Cooper, M.E.; Kern, T.S. \& Schmidt, A.M. (2009). Therapies for hyperglycaemia-induced diabetic complications: from animal models to clinical trials. Nature Reviews Drug Discovery, Vol.8, No.5, (May 2009), pp. :417-429. ISSN 1474-1776.

Camargo de Andrade, M.C.; Di Marco, G.S.; de Paulo Castro Teixeira, V.; Mortara, R. Sabatini, R.A.; Pesquero, J.B.; Boim, M.A.; Carmona, A.K.; Schor, N. \& Casarini, D.E. (2006). Expression and localization of N-domain ANG I-converting enzymes in mesangial cells in culture from spontaneously hypertensive rats. American Journal of Physiology. Renal Physiology, Vol.290, No.2, (February 2006), pp. F364-F375, ISSN 1931-857X.

Carey, R.M. \& Padia, S.H. (2008). Angiotensin AT2 receptors: control of renal sodium excretion and blood pressure. Trends in Endocrinology and Metabolism. Vol.19, No.3, (April 2008), pp. 84-87, ISSN 1043-2760. 
Carey, R.M. \& Siragy, H.M. (2003a). Newly recognized components of the renin-angiotensin system: potential roles in cardiovascular and renal regulation. Endocrine Reviews, Vol.24, No.3 (June 2003a), pp. 261-271, ISSN 0163-769X.

Carey, R.M. \& Siragy, H.M. (2003b). The intrarenal rennin-angiotensin system and diabetic nephropathy. Trends in Endocrinology and Metabolism, Vol.14, No.6, (August 2003b), pp. 274-281, ISSN 1043-2760.

Carey, R.M.; Wang, Z.Q. \& Siragy, H.M. (2000). Role of angiotensin type 2 receptor in the regulation of blood pressure and renal function. Hypertension, Vol.35, No.1 (Pt 2) , (January 2000), pp. 155-116, ISSN 0194-911X.

Casarini, D.E.; Carmona, A.K.; Plavnik, F.L.; Zanella, M.T.; Juliano, L. \& Ribeiro, A.B. (1995). Calcium channel blockers as inhibitors of angiotensin I-converting enzyme. Hypertension, Vol.26, No.6( Pt 2), (Dcember 1995), pp. 1145-1148, ISSN 0194-911X.

Casarini, D.E.; Plavinik, F.L.; Zanella, M.T.; Marson, O.; Krieger, J.E.; Hirata, I.Y. \& Stella, R.C. (2001). Angiotensin converting enzymes from human urine of mild hypertensive untreated patients resemble the N-terminal fragment of human angiotensin I-converting enzyme. International Journal of Biochemistry and Cell Biology, Vol.33, No.1, (January 2001), pp. 75-85, ISSN 1357-2725.

Chan, J.C.; Ko, G.T.; Leung, D.H.; Cheung, R.C.; Cheung, M.Y.; So, W.; Swaminathan, R.; Nicholls, M.G.; Critchley, J.A. \& Cockram, C.S. (2000). Long-term effects of angiotensin-converting enzyme inhibition and metabolic control in hypertensive type 2 diabetic patients. Kidney International, Vol.57, No.2, (February 2000), pp. 590600, ISSN 0085-2538.

Choudhury, D.; Tuncel, M. \& Levi, M. (2010). Diabetic nephropathy -- a multifaceted target of new therapies. Discovery Medicine, (November 2010), Vol.10, No.54, pp. 406-415, ISSN 1539-6509.

Colucci J.A.; Arita D.Y.; Cunha T.S.; Di Marco G.S.; Vio C.P.; Silva Filho A.P. \& Casarini D.E. (2011). Renin-angiotensin system may trigger kidney damage in NOD mice. Journal of Renin-Angiotensin-Aldosterone System, Vol.12, No.1, (March 2011), pp. 15-22, ISSN 1470-3203.

Cooper, M.E. \& Johnston, C.I. (2000). Optimizing treatment of hypertension in patients with diabetes. Journal of the American Medical Association, Vol.283, No.24, (June 2000), pp. 3177-3179, ISSN 0098-7484.

Cooper, M.E. (1998). Pathogenesis, prevention, and treatment of diabetic nephropathy. The Lancet, Vol.352, No.9123, (July 1998), pp. 213-219, ISSN 0140-6736.

Corvol, P.; Williams, T.A. (1998). Peptidyl-dipeptidase A/angiotensin 1-converting enzyme. In: Handbook of Proteolytic Enzymes. A.J. Barrett, N.D. Rawlings, J.F Woessner (Ed.), 1066-1076, Academic Press, ISBN 978-0-12-079610-6, San Diego, CA, USA.

Crackower, M.A.; Sarao, R.; Oudi,t G.Y.; Yagil, C.; Kozieradzki, I.; Scanga, S.E.; Oliveira-dosSantos, A.J.; da Costa, J.; Zhang, L.; Pei, Y.; Scholey, J.; Ferrario, C.M.; Manoukian, A.S.; Chappell, M.C.; Backx, P.H.;Yagil,Y. \& Penninger JM.. (2002). Angiotensinconverting enzyme 2 is an essential regulator of heart function. Nature, Vol.417, No.6891, pp. 822-8, ISSN 0028-0836.

D'Agati, V. \& Schmidt, A.M. (2010). RAGE and the pathogenesis of chronic kidney disease. Nature Review Nephrology, Vol.6, No.6, (Jun 2010), pp. 352-360, ISSN 1759-5061.

Dalla Vestra, M.; Saller, A.; Bortoloso, E.; Mauer, M. \& Fioretto, P. (2000). Structural involvement in type 1 and type 2 diabetic nephropathy. Diabetes $\mathcal{E}$ Metabolism, Vol.26 (Suppl 4), (July 2000), pp. 8-14, ISSN 1262-3636. 
Danilczyk, U. \& Penninger, J.M. (2006). Angiotensin-converting enzyme II in the heart and the kidney. Circulation Research, Vol.98, No.98, (March 2006), pp. 463-471, ISSN 0009-7330.

Danilczyk, U.; Eriksson, U.; Crackower, MA. \& Penninger, JM. (2003). A story of two ACEs. Journal of Molecular Medicine, Vol.81, No.4, (April 2003), pp. 227-34, ISSN 0946-2716.

Danser, A.H.J \& Schalekamp, M.A.D.H. (1996). Is there an internal cardiac renninangiotensin system? Heart, Vol.76, No.3 (suppl 3), (November 1996), pp. 28-32, ISSN 1355-6037.

De Andrade, M.C.; Affonso, R.; Fernandes, F.B.; Febba, A.C.; da Silva, I.D.; Stella, R.C.; Marson, O.; Jubilut, G.N.; Hirata, I.Y.; Carmona, A.K.; Corradi, H.; Acharya, K.R.; Sturrock, E.D.; Casarini, D.E. (2010). Spectroscopic and structural analysis of somatic and $\mathrm{N}$-domain angiotensin I-converting enzyme isoforms from mesangial cells from Wistar and spontaneously hypertensive rats. International Journal of Biological Macromolecules, Vol. 47, No. 2, (August 2010), pp. 238-43, ISSN 0141-8130.

De Gasparo, M. ; Catt, K.J. ; Inagami, T., Wright, J.W. ; Unger, T. (2000). International union of pharmacology. XXIII. The angiotensin II receptors. Pharmacological Reviews, Vol. 52, No. 3, (September 2000), pp. 415-472, ISSN 0031-6997.

De Gasparo, M.; Siragy, H.M.. (1999). The AT2 receptor: fact, fancy and fantasy. Regulatory Peptides, Vol. 81, No. (1-3), (May 1999), pp. 11-24, ISSN 0167-0115.

Declèves, A.E. \& Sharma, K. (2010). New pharmacological treatments for improving renal outcomes in diabetes. Nature Reviews Nephrology, Vol.6, No.6, (June 2010), pp. 371380, ISSN 1759-5061.

Deddish, P.A.; Wang, J.; Michel, B.; Morris, P.W.; Davidson, N.O.; Skidgel, R.A \&, Erdös, E.G. (1994). Naturally occurring active N-domain of human angiotensin Iconverting enzyme. Proceedings of the national academy of sciences of the United States of America, Vol.91, No.16, (August 1994), pp. 7807-7811, ISSN 0027-8424.

Ding, Y.; Davisson, R.L.; Hardy, D.O.; Zhu, L.J.; Merrill, D.C.; Catterall, J.F. \& Sigmund, C.D. (1997). The kidney androgen-regulated protein promoter confers renal proximal tubule cell-specific and highly androgen-responsive expression on the human angiotensinogen gene in transgenic mice. Journal of Biological Chemistry, Vol.272, No.44, (October 1997), pp. 28142-28148, ISSN 0021-9258.

Donoghue, M.; Hsieh, F.; Baronas, E.; Godbout, K.; Gosselin, M.; Stagliano, N.; Donovan, M.; Woolf, B.; Robison, K.; Jeyaseelan, R.; Breitbart, R.E \& Acton, S. (2000). A novel angiotensin-converting enzyme-related carboxypeptidase (ACE2) converts angiotensin I to angiotensin 1-9. Circulation Research, Vol.87, No.5, (September 2000), pp. E1-E9, ISSN 0009-7330.

Eckel, R.H.; Grundy, S.M. \& Zimmet, P.Z. (2005). The metabolic syndrome. The Lancet,

Elliott, M.D.; Kapoor, A.; Parker, M.A.; Kaufman, D.B.; Bonow, R.O \& Gheorghiade, M. (2001). Improvement in hypertension in patients with diabetes mellitus after kidney/pancreas transplantation. Circulation, Vol.104, No.5, (July 2001), pp. 563569. ISSN 0009-7322.

Erdös, E.G. (1976). Conversion of angiotensin I to angiotensin II. American Journal of Medicine, Vol.60, No.6, (May 1976), pp. 749-759, ISSN 0002-9343.

Farag, Y.M. \& Gaballa, M.R. (2011). Diabesity: an overview of a rising epidemic. Nephrology Dialysis Transplantation, Vol.26, No.1 (January 2011), pp. 28-35, ISSN 0931-0509. 
Ferrari, R. (2005). Angiotensin-converting enzyme inhibition in cardiovascular disease: evidence with perindopril. Expert Reviews of Cardiovascular Therapy, Vol.3, No.1 (January 2005), pp. 15-29, ISSN: 1477-9072.

Ferrario, C.; Abdelhamed, A.I \& Moore, M. (2004). Angiotensin antagonists in hypertension, heart failure, and diabetic nephropathy: focus in losartan. Current Medical Research and Opinion, Vol.20, No.3, (March 2004), pp. 279-93, ISSN 0300-7995.

Ferrario, C.M. (2006). Angiotensin-converting enzyme 2 and angiotensin-(1-7): an evolving story in cardiovascular regulation. Hypertension, Vol.47, No.3, (March 2006), pp. 515-21, ISSN 0194-911X.

Ferrario, CM. \& Varagic, J. (2010). The ANG-(1-7)/ACE2/mas axis in the regulation of nephron function. American Journal of Physiology Renal Physiology, Vol.298, No.6, (June 2010), pp. F1297-1305. Epub 2010 Apr 7. Review. Erratum in: American Journal of Physiology Renal Physiology, Vol.299, No.6, (December 2010), pp. F1515, ISSN 0363-6127

Ferrario, CM. (2011). ACE2: more of Ang-(1-7) or less Ang II? Current Opinion in Nephrology and Hypertension, Vol.20, No.1, pp. 1-6, ISSN 1062-4821.

Folli, F.; Corradi, D.; Fanti, P.; Davalli, A.; Paez, A.; Giaccari, A.; Perego, C. \& Muscogiuri, G. (2011). The Role of Oxidative Stress in the Pathogenesis of Type 2 Diabetes Mellitus Micro- and Macrovascular Complications: Avenues for a Mechanistic-Based Therapeutic Approach. Current Diabetes Reviews, (August 2011), [Epub ahead of print], ISSN 1573-399898

Gembardt, F.; Sterner-Kockm A.;Imboden, H.; Spalteholz, M.; Reibitz, F.; Schultheiss, H.P.; Siems, W.E. \& Walther, T. (2005). Organ-specific distribution of ACE2 mRNA and correlating peptidase activity in rodents. Peptides, Vol.26, No.7, (July 2005), pp. 1270-1277, ISSN 0196-9781.

Giacchetti, G.; Sechi, L.A.; Rilli, S. \& Carey, R.M. (2005). The renin-angiotensin-aldosterone system, glucose metabolism and diabetes. Trends in Endocrinology and Metabolism, Vol.16, No.3, (April 2005), pp. 120-126, ISSN 1043-2760.

Gilbert, RE.; Cox, A.; Wu, LL.; Allen, TJ.; Hulthen, L.; Jerums, G. \& Cooper, M.E. (1998). Expression of transforming growth factor- 1 and type IV collagen in the renal tubulointerstitium in experimental diabetes: effects of angiotensin converting enzyme inhibition. Diabetes, Vol.47, pp. 414-422, ISSN 0012-1797.

Gillespie, E.L.; White, C.M.; Kardas, M.; Lindberg, M. \& Coleman, C.L. (2005). The impact of ACE inhibitors or angiotensin II type 1 receptor blockers on the development of new-onset type 2 diabetes. Diabetes Care, Vol.28, No.9 (September 2005), pp. 22612266, ISSN 0149-5992.

Gress, T.W.; Nieto, F.J.; Shahar, E.; Wofford, M.R. \& Brancati, F.L. (2000). Hypertension and antihypertensive therapy as risk factors for type 2 diabetes mellitus. Atherosclerosis Risk in Communities Study. The New England Journal of Medicine, Vol.342, No.13, (March 2000), pp. 905-912, ISSN 0028-4793.

Guarnieri, G.; Zanetti, M.; Vinci, P.; Cattin, M.R.; Pirulli, A. \& Barazzoni, R. (2010) Metabolic syndrome and chronic kidney disease. Journal of Renal Nutrition, Vol.20, Suppl.5, (September 2010), pp. S19-S23, ISSN 1051-2276.

Guimaraes, P.B.; Alvarenga, E.C.; Siqueira, P.D.; Paredes-Gamero, E.J.; Sabatini, R.A.; Morais, R.L.T.; Reis, R.I.; Santos, E.L.; Teixeira, L.G.D.; Casarini, D.E.; Martin, R.P.; Shimuta, S.I.; Carmona, A.K.; Nakaie, C.R.; Jasiulionis, M.G.; Ferreira, A.T.; Pesquero, J.L.; Oliveira, S.M.; Bader, M.; Costa-Neto, C.M. \& Pesquero, J.B. (2011). 
Angiotensin II Binding to Angiotensin I-Converting Enzyme Triggers Calcium Signaling. Hypertension, Vol.57, No.5, (May 2011), pp. 965-972, ISSN 0194-911X.

Gupta, A.K.; Dahlof, B.; Dobson, J.; Sever, P.S.; Wedel, H.; Poulter, N.R. \& AngloScandinavian Cardiac Outcomes Trial Investigators. (2008). Determinants of newonset diabetes among 19,257 hypertensive patients randomized in the AngloScandinavian Cardiac Outcomes Trial--Blood Pressure Lowering Arm and the relative influence of antihypertensive medication. Diabetes Care, Vol.31, No.5, (May 2008), pp. 982-988, ISSN 0149-5992.

Hall, J.E. (2003). Historical perspective of the renin-angiotensin system. Molecular Biotechnology, Vol.24, No.1, pp. 27-39, ISSN 1073-6085.

Hall, J.E.; da Silva, A.A.; do Carmo, J.M.; Dubinion, J.; Hamza, S.; Munusamy, S.; Smith, G. \& Stec, D.E. (2010). Obesity-induced hypertension: role of sympathetic nervous system, leptin, and melanocortins. The Journal of Biological Chemistry, Vol.285, No.23, (June 2010), pp. 17271-17276, ISSN 0021-9258.

Handelsman, Y. (2011). Diabetes and hypertension: a comprehensive report on management and the prevention of cardiovascular and renal complications. The Journal of Clinical Hypertension, Vol.13, No.4, (April 2011), pp. 221-223, ISSN 1524-6175.

Harmer, D.; Gilbert, M.; Borman, R. \& Clark, KL. (2002). Quantitative mRNA expression profiling of ACE 2, a novel homologue of angiotensin converting enzyme. Federation of European Biochemical Societies Letters, Vol.4, No.532, (December 2002), pp. 107-10, ISSN 0014-5793.

Hayden, M.R.; Sowers, K.M.; Pulakat, L.; Joginpally, T.; Krueger, B.; Whaley-Connell, A. \& Sowers, J.R. (2011). Possible Mechanisms of Local Tissue Renin-Angiotensin System Activation in the Cardiorenal Metabolic Syndrome and Type 2 Diabetes Mellitus. Cardiorenal Medicine, Vol.1, No.3, (June 2011), pp. 193-210, ISSN 1664-3828.

Heart Outcomes Prevention Evaluation (HOPE) Study Investigators. (2000). Effects of ramipril on cardiovascular and microvascular outcomes in people with diabetes mellitus: results of the HOPE study and MICRO-HOPE substudy. The Lancet, Vol.355, No9200, (January 2000), pp. 253-269. ISSN 0140-6736. Erratum in The Lancet, Vol.356, No. 9232, (September 2000), pp. 860.

Houston, M.C.; Basile, J.; Bestermann, W.H.; Egan, B.; Lackland, D.; Hawkins, R.G.; Moore, M.A.; Reed, J.; Rogers, P.; Wise, D. \& Ferrario, C.M. Addressing the global cardiovascular risk of hypertension, dyslipidemia, and insulin resistance in the southeastern United States. American Journal of the Medical Sciences, Vol.329, No.6, (June 2005), pp. 276-291, ISSN 0002-9629.

Hsieh, T.J.; Fustier, P.; Zhang, S.L.; Filep, J.G.; Tang, S.S.; Ingelfinger, J.R.; Fantus, I.G.; Hamet, P.; \& Chan JS. (2003). High glucose stimulates angiotensinogen gene expression and cell hypertrophy via activation of the hexosamine biosynthesis pathway in rat kidney proximal tubular cells. Endocrinology, vol.144, No.10, (October 2003), pp. 4338-4349, ISSN 0013-7227.

Hsueh, W.A. \& Wyne, K. (2011). Renin-Angiotensin-aldosterone system in diabetes and hypertension. Journal of Clinical Hypertension (Greenwich), Vol.13, No.4, (April 2011), pp. 224-37, ISSN 1524-6175.

$\mathrm{Hu}$, F.B. (2011). Globalization of diabetes: the role of diet, lifestyle, and genes. Diabetes Care, Vol.34, No.6, (June 2011), pp. 1249-1257, ISSN 0149-5992.

Huang, W.; Gallois, Y.; Bouby, N.; Bruneval, P.; Heudes, D.; Belair, M.F.; Krege, J.H.; Meneton, P.; Marre, M.; Smithies, O. \& Alhenc-Gelas, F. (2001). Genetically 
increased angiotensin I-converting enzyme level and renal complications in diabetic mouse. Proceedings of the National Academy of Sciences of the United States of America, Vol.98, No. 23, (November 2001), pp. 13330-13334, ISSN 0027-8424.

Hunyady, L. \& Catt, K.J. (2006). Pleitropic AT1 receptor signaling pathways mediating physiological and pathogenic actions of angiotensin II. Molecular Endocrinology, Vol.20, No.5, (May 2006), pp. 953-970, ISSN 0888-8809.

Ichihara, A.; Suzuki, F.; Nakagawa, T.; Kaneshiro, Y.; Takemitsu, T.; Sakoda, M.; Nabi, A.H.; Nishiyama, A.; Sugaya, T.; Hayashi, M. \& Inagami, T. (2006). Prorenin receptor blockade inhibits development of glomerulosclerose in diabetic angiotensin II type 1a receptor deficient mice. Journal of the American Society of Nephrology. Vol.17, No.7, (July 2006), pp. 1950-1961, ISSN 1046-6673.

International Diabetes Federation: The Diabetes Atlas, 4th Edition. International Diabetes Federation, 2009. Brussels, http://www.idf.org/diabetesatlas.

Isomaa, B.; Almgren, P.; Tuomi, T.; Forsén, B.; Lahti, K.; Nissén, M.; Taskinen, M.R. \& Groop, L. (2001). Cardiovascular morbidity and mortality associated with the metabolic syndrome. Diabetes Care, Vol.24, No.4, (April 2001), pp. 683-689, ISSN 1062-4821.

Izzo, R.; de Simone, G.; Chinali, M.; Iaccarino, G.; Trimarco, V.; Rozza, F.; Giudice, R.; Trimarco, B. \& De Luca, N.; (2009). Insufficient control of blood pressure and incident diabetes. Diabetes Care, Vol. 32, No.5, (May 2009), pp. 845-850, ISSN 0149-5992.

Jandeleit-Dahm, K. \& Cooper, M.E. (2002). Hypertension and diabetes. Current Opinion in Nephrology and Hypertension, Vol.11, No.2, (March 2002), pp. 221-228, ISSN 1062-4821.

Jaspard, E.; Wei, L. \& Alhenc-Gelas, F. (1993). Differences in the properties and enzymatic specificities of the two active sites of angiotensin I-converting enzyme (kininase II). Studies with bradykinin and other natural peptides. Journal of Biological Chemistry, Vol.268, No.13, (May 1993), pp. 9496-9503, ISSN 0021-9258.

Kambayashi, Y.; Bardhan, S.; Takahashi, K.; Tsuzuki, S.; Inui, H.; Hamakubo, T.; Inagami, T. (1993). Molecular cloning of a novel angiotensin II receptor isoform involved in phosphotyrosine phosphatase inhibition. Journal of Biological Chemistry, Vol. 268, No. 33, (November 1993), pp. 24543-24546, ISSN 0021-9258.

Kang, J.J.; Toma, I.; Sipos, A.; Meer, E.J.; Vrgas, S.L. \& Peti-Pertedi J. (2008). The collecting duct is the major source of pro-renin in diabetes. Hypertension, Vol.51, No.6, (June 2008), pp. 1597-1604, ISSN 0194-911X.

Keller, C.K.; Bergis, K.H.; Fliser, D. \& Ritz, E. (1996). Renal findings in patients with shortterm type 2 diabetes. Journal of the American Society of Nephrology, Vol.7, No.12, (December 1996), pp. 2627-2635, ISSN 1046-6673.

Kobori, H.; Harrison-Bernard, L.M. \& Navar, L.G. (2001). Enhancement of angiotensinogen expression in angiotensin II-dependent hypertension. Hypertension, Vol.37, No.5, (May 2001), pp. 1329-1335, ISSN 0194-911X.

Kobori, H.; Nangaku, M.; Navar, G. \& Nishiyama, A. (2007). The intrarenal reninangiotensin system: from physiology to the pathobiology of hypertension and kidney disease. Pharmacological Reviews, Vol.59, No.3, (September 2007), pp. 251287, ISSN 0031-6997.

Kobori, H.; Nishiyama, A.; Harrison-Bernard, L.M. \& Navar, L.G. (2003). Urinary angiotensinogen as an indicator of intrarenal angiotensin status in hypertension. Hypertension, Vol.41, No.1, (January 2003), pp. 42-49, ISSN 0194-911X. 
Kohlstedt, K.; Brandes, R.P.; Muller-Esterl, W.; Busse, R. \& Fleming, I. (2004). Angiotensinconverting enzyme is involved in outside-in signaling in endothelial cells. Circulation Research, Vol.94, No.1, (January 2004), pp. 60-67, ISSN 0009-7330.

Kotsis, V.; Stabouli, S.; Papakatsika, S.; Rizos, Z. \& Parati, G. (2010) Mechanisms of obesityinduced hypertension. Hypertension Research, Vol.33, No.5, (May 2010), pp. 386-393, ISSN 0916-9636.

Lambert, D.W.; Clarke, N.E.; Turner, A.J. (2010). Not just angiotensinases: new roles for the angiotensin-converting enzymes. Cellular and Molecular Life Sciences, Vol. 67, No. 1, (January 2010), pp. 89-98, ISSN 1420-682X.

Lattion, A.L.; Soubrier, F.; Allegrini, J.; Hubert, C.; Corvol, P. \& Alhenc-Gelas, F. (1989). The testicular transcript of the angiotensin Iconverting enzyme encodes for the ancestral, non-duplicated form of the enzyme. FEBS Letters, Vol.252, No(1-2), (July 1989), pp. 99-104, ISSN 0014-5793.

Lavoie, J.L. \& Sigmund, C.D. (2003). Minireview: overview of the rennin-angiotensin system-an endocrine and paracrine system. Endocrinology, Vol144, (June 2003), pp. 2179-2183, ISSN 0013-7227.

Lewis, E.J.; Hunsicker, L.G.; Bain, R.P. \& Rohde, R.D. (1993). The Collaborative Study Group. The effect of angiotensin-converting-enzyme inhibition on diabetic nephropathy. The New England Journal of Medicine, Vol.329, No.20, (November 1993), pp. 1456-1462, ISSN 0028-4793.

Lewis, E.J.; Hunsicker, L.G.; Clarke, W.R.; Berl, T.; Pohl, M.A.; Lewis, J.B.; Ritz, E.; Atkins, R.C.; Rohde, R. \& Raz, I. (2001). Renoprotective effect of the angiotensin-receptor antagonist irbesartan in patients with nephropathy due to type 2 diabetes. The New England Journal of Medicine, Vol.345, No.12, (September 2001), pp. 851-860, ISSN 0028-4793.

Maia, L.G.; Ramos, M.C.; Fernandes, L.; de Carvalho, M.H.C.; Campagnole-Santos, M.J. \& Souza dos Santos, R.A. (2004). Angiotensin -(1-7) antagonist A-779 attenuates the potentiation of bradykinin by captopril in rats. Journal of Cardiovascular Pharmacology, Vol.43, No.5, (May 2004), pp. 685-691, ISSN 0160-2446.

Makino, S.; Kunimoto, K.; Muraoka, Y.; Mizushima, Y.; Katagiri, K. \& Tochino, Y. (1980). Breeding of a non-obese, diabetic strain of mice. Jikken Dobutsu, Vol.29, No.1, (January 1980), pp. 1-13, ISSN 0007-5124.

Marques, G.D.; Quinto, B.M.; Plavinik, F.L.; Krieger, J.E.; Marson, O. \& Casarini, D.E. (2003). $\mathrm{N}$-domain angiotensin I-converting enzyme with $80 \mathrm{kDa}$ as a possible genetic marker of hypertension. Hypertension, Vol.42, No.4, (October 2003), pp. 693-701, ISSN 0194-911X.

Matsubara, H. (1998). Pathophysiological role of angiotensin II type 2 receptor in cardiovascular and renal diseases. Circulation Research, Vol. 83, ( September 1998), pp. 1182-1191, ISSN 0009-7330.

Mervaala, E.M.; Müller, D.N.; Park, J.K.; Schmidt, F.; Löhn, M.; Breu, V.; Dragun, D.; Ganten, D.; Haller, H. \& Luft, F.C. (1999). Monocyte infiltration and adhesion molecules in a rat model of high human renin hypertension. Hypertension, Vol.33, No.1, Pt 2, (January 1999), pp. 389-395, ISSN 0194911X.

Miao, Y.; Smink, P.A.; de Zeeuw, D. \& Lambers Heerspink, H.J. (2011). Drug-induced changes in risk/biomarkers and their relationship with renal and cardiovascular long-term outcome in patients with diabetes. Clinical Chemistry. Vol.57, No.2, (February 2011), pp. 186-195, ISSN 0009-9147. 
Mogensen, CE. (1976). Renal function changes in diabetes. Diabetes, Vol.25, (2 Suppl), (1976), pp. 872-9, ISSN 0012-1797.

Moriguchi, A.; Tallant, EA.; Matsumura, K.; Reilly, TM.; Walton, H.; Ganten, D. \& Ferrario, C.M. (1995). Opposing actions of angiotensin-(1-7) and angiotensin II in the brain of transgenic hypertensive rats. Hypertension, Vol. 25, No.6, pp. 1260-5, ISSN 0194911X.

Mukai, Y.; Shimokawa, H.; Higashi, M.; Morikawa, K.; Matoba, T.; Hiroki, J.; Kunihiro, I.; Talukder, H.M. \& Takeshita, A. (2002). Inhibition of renin-angiotensin system ameliorates endothelial dysfunction associated with aging in rats. Arteriosclerosis, Thrombosis and Vascular Biology, Vol.22 (September 2002), pp. 1445-1450, ISSN 1049-8834.

Mukoyama, M.; Nakajima, M.; Horiuchi, M.; Sasamura, H.; Pratt, R.E.; Dzau, V.J. (1993). Expression cloning of type-2 angiotensin II receptor reveals a unique class of seventransmembrane receptors. The Journal of Biological Chemistry 1993;268:24539-42, ISSN 0021-9258.

Nakajima, M.; Hutchinson, H.G.; Fujinaga, M.; Hayashida, W.; Morishita R.; Zhang, L.; Horiuchi, M.; Pratt, R.E. \& Dzau, V.J. (1995). The angiotensin II type 2 (AT2) receptor antagonizes the growth effects of the AT1 receptor: gain-of-function study using gene transfer. Proceedings of the National Academy of Sciences of United States of America, Vol. 10, No. 3, (June 1998), pp. 188-193. ISSN 0027-8424.

National Institute of Diabetes and Digestive and Kidney Diseases. US Renal Data Systems: USRDS 2010 annual data report: Atlas of End Stage Renal Disease in the United States. National Institues of Health, Bethesda, Maryland, USA, 2010.

Navar, L.G.; Harrison-Bernard, L.M.; Nishiyama, A.; Kobori, H. (2002). Regulation of intrarenal angiotensin II in hypertension. Hypertension, Vol., 39, No. (2 Pt 2), (February 2002), pp. 316-322, ISSN 0194-911X.

Navar, L.G. \& Harrison-Bernard LM. (2000). Intrarenal angiotensin II augmentation in angiotensin II dependent hypertension. Hypertension Research, Vol.23, No.4, (July 2000), pp. 291-301, ISSN 0916-9636.

Navar, L.G.; Lewis, L.; Hymel, A.; Braan, B. \& Mitchel, K.D. (1994). Tubular fluid concentrations and kidney contents of angiotensins I and II in anesthetized rats. Journal of the American Society of Nephrology, Vol.5, No.4, (October 1994), pp. 11531158, ISSN 1046-6673.

Navar, LG.; Kobori, H.; Prieto, MC. \& Gonzalez-Villalobos, RA. (2011a). Intratubular reninangiotensin system in hypertension. Hypertension, Vol.57, No.3, (March 2011a), pp. 355-62, ISSN 0194911X.

Navar, LG.; Prieto, MC.; Satou, R. \& Kobori, H. (2011b). Intrarenal angiotensin II and its contribution to the genesis of chronic hypertension. Current Opinion in Pharmacology, Vol.11, No.2, (April 2011b), pp. 180-6, ISSN 1471-4892.

Nguyen, G.; Contrepas, A. (2008). Physiology and pharmacology of the (pro)renin receptor. Current Opinion in Pharmacology, Vol. 8, No. 2, (April 2008), pp. 127-132, ISSN 1471-4892.

Nguyen, G. (2011). Renin and prorenin receptor in hypertension: what's new? Current Hypertension Reports, Vol. 13, No. 1, (February 2011), pp. 79-85, ISSN 1522-6417.

Nguyen, G.; Delarue, F.; Burckle, C.; Bouzhir, L.; Giller, T. \& Sraer, J.D. (2002). Pivotal role of the renin/prorenin receptor in angiotensin II production and cellular responses to renin. Journal of Clinical Investigation, Vol109, No.11, (June 2002), pp. 1417-1427, 2002, ISSN 0021-9738 
Oudit, G.Y.; Liu, G.C.; Zhong, J.; Basu, R.; Chow, F.L.; Zhou, J.; Loibner, H.; Janzek, E.; Schuster, M.; Penninger, J.M.; Herzenberg, A.M.; Kassiri, Z. \& Scholey, J.W. (2010). Human recombinant ACE2 reduces the progression of diabetic nephropathy. Diabetes, Vol.59, No.2, (February 2010), pp. 29-38, ISSN 0012-1797.

Parving, H.H.; Lehnert, H.; Bröchner-Mortensen, J.; Gomis, R.; Andersen, S. \& Arner, P. (2001). Irbesartan in Patients with Type 2 Diabetes and Microalbuminuria Study Group.The effect of irbesartan on the development of diabetic nephropathy in patients with type 2 diabetes. The New England Journal of Medicine. Vol.345, No.12, (September 2001), pp. 870-878, ISSN 0028-4793.

Paul, M.; Mehr, A.P. \& Kreutz, R. (2006). Physiology of local angiotensin systems. Physiological Reviews, Vol.86, (July 2006), pp. 747-781, ISSN 0031-9333.

Poulsen, P.L.; Hansen, K.W. \& Mogensen, C.E. (1994). Ambulatory blood pressure in the transition from normo- to microalbuminuria. A longitudinal study in IDDM patients. Diabetes, Vol.43, No.10, (October 1994), pp. 1248-1253, ISSN 0012-1797.

Prescott, G.; Silversides, D.W. \& Reudelhuber, T.L. (2002). Tissue activity of circulanting prorenin. American Journal of Hypertension, Vol.15, No.3, (March 2002), pp. 280-285, ISSN 0895-7061.

Prieto-Carrasquero, M.C.; Harrison-Bernard, L.M.; Kobori, H.; Ozawa, Y.; Hering-Smith, K.S.; Hamm, L.L. \& Navar, L.G. (2004). Enhancement of collecting duct rennin in angiotensin II-dependent hypertensive rats. Hypertension, Vol.44, No.2, (August 2004), pp. 223-229, ISSN 0194-911X.

Ravid, M.; Brosh, D.; Levi, Z.; Bar-Dayan, Y.; Ravid, D. \& Rachmani, R. (1998). Use of enalapril to attenuate decline in renal function in normotensive, normoalbuminuric patients with type 2 diabetes mellitus. A randomized, controlled trial. Annals of Internal Medicine, Vol. 128, No.12, Pt 1, (June 1998), pp. 982-988, ISSN 0003-4819.

Redublo Quinto, B.M, Camargo de Andrade, M.C.; Ronchi, F.A.; Santos, E.L.; Correa, S.A.A.; Shimuta, S.I.; Pesquero, J.B.; Mortara, R.A. \& Casarini, D.E. (2008). Expression of angiotensin I-converting enzymes and bradykinin B2 receptors in mouse inner medullary-collecting duct cells. International Immunopharmacology, Vol.8, No.2, (February 2008), pp. 254-260, ISSN 1567-5769.

Ribeiro-Oliveira Jr, A.; Nogueira, A.I.; Pereira, R.M.; Boas, W.W.V.; Santos, R.A.S. \& Simoes e Silva, A.C. (2008). The renin-angiotensin system and diabetes: an update. Vascular Health and Risk Management, Vol.4, No.4, (2008), pp. 787-803, ISSN 1176-6344.

Riordan, J.F. (2003). Angiotensin-I-converting enzyme and its relatives. Genome Biology, Vol. 4, No. 8, (2003), pp. 225, ISSN 1465-6906.

Ronchi, F.A.; Andrade, M.C.; Carmona, A.K.; Krieger, J.E. \& Casarini, D.E. (2005). N-domain angiotensin-converting enzyme isoform expression in tissues of Wistar and spontaneously hypertensive rats. Journal of Hypertension, Vol.23, No.10, (October 2005), pp. 1869-78, ISSN 0263-6352.

Ronchi, F.A.; Irigoyen, M.C. \& Casarini DE. Association of somatic and N-domain angiotensin-converting enzymes from Wistar rat tissue with renal dysfunction in diabetes mellitus. Journal of the Renin-Angiotensin-Aldosterone System, Vol.8, No.1, (March 2007), pp. 34-41, ISSN 1470-3203.

Rosivall, L. (2009). Intrarenal renin-angiotensin system. Molecular and cellular Endocrinology, Vol.302, No. 2, (April 2009), pp. 185-192, ISSN 0303-7207.

Rousseau, A.; Michaud, A.; Chauvet, M.T.; Lenfant, M. \& Corvol, P. (1995). The hemoregulatory peptide N-acetyl-Ser-Asp-Lys-Pro is a natural and specific 
substrate of the $\mathrm{N}$-terminal active site of human angiotensin-converting enzyme. Journal of Biological Chemistry, Vol.270, No.8, (February 1995), pp. 3656-3661, ISSN 0021-9258.

Ruggenenti, P.; Cravedi, P. \& Remuzzi, G. (2010). The RAAS in the pathogenesis and treatment of diabetic nephropathy. Nature Reviews Nephrology, Vol.6, No.6, (June 2010), pp. 319-330, ISSN 1759-5061.

Santos, R.A. \& Ferreira, A.J. (2007). Angiotensin 1-7 and renin-angiotensin system. Current Opinion Nephrology and Hypertension, Vol.16, No.2, (March 2007), pp. 122-128, ISSN $1062-4821$.

Santos, R.A.; Frezard, F. \& Ferreira, A.J. (2005). Angiotensin-(1-7): blood, heart, and blood vessels. Current Medicinal Chemistry - Cardiovascular \& Hematological Agents, Vol.3, No.4, (October 2005), pp. 383-91, ISSN 1568-0169.

Santos, R.A.; Simoes e Silva, A.C.; Maric, C.; Silva, D.M.; Machado, R.P.; de Buhr, I.; Heringer-Walther, S.; Pinheiro, S.V.; Lopes, M.T.; Bader, M.; Mendes, E.P.; Lemos, V.S.; Campagnole-Santos, M.J.; Schultheiss, H.P.; Speth, R. \& Walther, T. (2003). Angiotensin -(1-7) is an endogenous ligand for the $G$ protein-coupled receptor Mas. Proceedings of the National Academy of Sciences of the United States of America, Vol.100, No.14, (July 2003) pp. 8258-8263, ISSN 0027-8424.

Saris, J.J.; Derkx, F.H.; De Bruin, R.J.; Dekkers, D.H.; Lamers, J.M.; Saxena, P.R.; Schalekamp, M.A.; Jan Danser, A.H. High-affinity prorenin binding to cardiac man-6-P/IGF-II receptors precedes proteolytic activation to renin. American Journal of Physiology, Vol. 280, No. 4, (April 2001), pp. H1706-H1715. ISSN 1040-0605.

Sato, A.; Hayashi, K.; Naruse, M. \& Saruta, T. (2003). Effectiveness of aldosterone blockade in patients with diabetic nephropathy. Hypertension, Vol.41, No.1, (November 2003), pp. 64-68, ISSN 0194-911X.

Senanayake, P.; Drazba, J.; Shadrach. K.; Milsted, A.; Rungger-Brandle, E.; Nishiyama, K.; Miura, S.; Karnik. S.; Sears, J.E. \& Hollyfield, J.G. (2007). Angiotensin II and its receptor subtypes in the human retina. Investigative Ophthalmology $\mathcal{E}$ Visual Science, Vol.48, No.7, (July 2007), pp. 3301-3311, ISSN 0146-0404.

Senbonmatsu, T.; Saito, T.; Landon, E.J.; Watanabe, O.; Price Jr, E.; Roberts, R.L.; Imboden, H.; Fitzgerald, T.G, Gaffney, F.A \& Inagami. (2003). A novel angiotensin II type 2 receptor signaling pathway: possible role in cardiac hypertrophy. The European Molecular Biology Organization Journal (EMBO). Vol 22, No. 24, (December 2003), pp. 6471-6482, ISSN 0261-4189.

Shaltout, H.A.; Westwood, B.M.; Averil,1 D.B.; Ferrario, C.M.; Figueroa, J.P.; Diz, D.I.; Rose, J.C. \& Chappell, M.C. (2007). Angiotensin metabolism in renal proximal tubules, urine, and serum of sheep: evidence for ACE2-dependent processing of angiotensin II. American Journal of Physiology Renal Physiology, Vol.292, No.1, (January 2007), pp. F82-F91, ISSN 1931-857X

Sharma, R.; Sharma, M.; Reddy, S.; Savin, V.J.; Nagaria, A.M. \& Wiegmann, T.B. (2006). Chronically increased intrarenal angiotensin II causes nephropathy in an animal model of type 2 diabetes. Frontiers in Bioscience, Vol.11, (January 2006), pp. 968-976, ISSN 1093-4715.

Touyz, R.M.; Schiffrin, E.L. (2000). Signal transduction mechanisms mediating the physiological and pathophysiological actions of angiotensin II in vascular smooth muscle cells. Pharmacological Reviews, Vol. 52, No. 4, (December 2000), pp. 639-672, ISSN 0031-6997. 
Sowers, J.R.; Epstein, M. \& Frohlich, E.D. (2001). Diabetes, hypertension, and cardiovascular disease: an update. Hypertension, Vol.37, No.4, (April 2001), pp. 1053-1059, ISSN 0194911X

Staessen, J.A.; Li Y. \& Richard, T. (2006). Oral renin inhibitors. Lancet, Vol.368, No.9545, (October 2006), pp. 1449-56, ISSN 0140-6736.

Stoll, M. \& Unger, T. Angiotensin and its AT2 receptor: new insights into an old system. Regulatory Peptides. Vol. 99, No. (2-3), (June 2001), pp. 175-182, ISSN 0167-0115.

Tanaka, H.; Shiohira, Y.; Uezu, Y.; Higa, A. \& Iseki, K. (2006). Metabolic syndrome and chronic kidney disease in Okinawa, Japan. Kidney International, Vol.69, No.2, (January 2006), pp. 369-374. ISSN 0085-2538

Tikellis, C.; Johnston, C.I.; Forbes, J.M.; Burns, W.C.; Burrell, L.M.; Risvanis, J. \& Cooper, M.E. (2003). Characterization of renal angiotensin-converting enzyme 2 in diabetic nephropathy. Hypertension, (Vol.41, No.3, (March 2003), pp. 392-7, ISSN 0194-911X.

Tikellis, C.; Wookey, P.J.; Candido, R.; Andrikopoulos, S.; Thomas, M.C \& Cooper, M.E. (2004). Improved islet morphology after blockade of the renin-angiotensin system in the ZDF rat. Diabetes, Vol.53, No.4, (April 2004), pp. 989-997, ISSN 0012-1797.

Tipnis, S.R.; Hooper, N.M.; Hyde, R.; Karran, E.; Christie, G. \& Turner, A.J. (2000). A human homolog of angiotensin-converting enzyme. Cloning and functional expression as a captopril-insensitive carboxypeptidase. Journal of Biological Chemistry, Vol.275, No.43, (October 2000), pp. 33238-33243), ISSN 0021-9258.

Touys \& Schiffrin. (2000). Signal transduction mechanisms mediating the physiological and pathophysiological actions of angiotensin II in vascular smooth muscle cells. Pharmacological Reviews, Vol.52, (December 2000), pp. 639-72, ISSN 0031-6997.

Unger, T. \& Sandmann, S. (2000). Angiotensin receptor blocker selectivity at the AT1- and AT2-receptors: conceptual and clinical effects. Journal of Renin-AngiotensinAldosterone System, Vol. 1, (suppl 2), (December 2000), pp. S6-S9, ISSN 1470-3203.

Unger, T.; Culman, J. \& Gohlke, P. (1998). Angiotensin II receptor blockade and end-organ protection: pharmacological rationale and evidence. Journal of Hypertension, Vol.16, (suppl7), pp. S3-9, ISSN 0263-6352.

Van Buren, P.N. \& Toto, R. (2011). Hypertension in diabetic nephropathy: epidemiology, mechanisms, and management. Advances in chronic kidney disease, Vol.18, No.1, (January 2011), pp. 28-41, ISSN 1548-5595.

Velloso, L.A.; Folli, F.; Perego, L. \& Saad, M.J. (2006). The multi-faceted cross-talk between the insulin and angiotensin II signaling systems. Diabetes/metabolism Research and Reviews, Vol.22, No.2, (March 2006), pp. 98-107, ISSN 1520-7552.

Vickers, C.; Hales, P.; Kaushik, V.; Dick, L.; Gavin, J.; Tang, J.; Godbout, K.; Parsons, T.; Baronas, E.; Hsieh, F.; Acton, S.; Patane, M.; Nichols, A. \& Tummino, P. (2002). Hydrolysis of biological peptides by human angiotensin-converting enzymerelated carboxypeptidase. Journal of Biological Chemistry, Vol.277, No.17, (April 2002), pp. 14838-43, ISSN 0021-9258.

Vidotti, D.B.; Casarini, D.E.; Cristovam, P.C.; Leite, C.A.; Schor, N. \& Boim, M.A. (2004). High glucose concentration stimulates intracellular renin activity and angiotensin II generation in rat mesangial cells. American Journal of Physiology - Renal Physiology, Vol.286, No.6, (June 2004), pp. F1039-1045, ISSN 0363-6127..

Wehbi, GJ.; Zimpelmann, J.; Carey, RM.; Levine, DZ. \& Burns, KD. (2001). Early streptozotocin-diabetes mellitus downregulates rat kidney $\mathrm{AT}(2)$ receptors. 
American Journal Physiology Renal Physiology, Vol.280, No.2, (February 2001), pp. F254-65, ISSN 1931-857X

Wei, L.; Alhenc-Gelas, F.; Corvol, P. \& Clauser, E. (1991). The two homologous domains of human angiotensin I-converting enzyme are both catalytically active. Journal of Biological Chemistry, Vol.266, No.14, (May 1991), pp. 9002-9008, ISSN 0021-9258.

Williams, T.A.; Michaud, A.; Houard, X.; Chauvet, M.T.; Soubrier, F.; Corvol, P. (1996) Drosophila melanogaster angiotensin I-converting enzyme expressed in Pichia pastoris resembles the $\mathrm{C}$ domain of the mammalian homologue and does not require glycosylation for secretion and enzymatic activity. Biochemical Journal, Vol. 318, (Pt 1), (August 1996), pp. 125-131, ISSN 0264-6021

Williams, B. (1994). Insulin resistance: the shape of things to come. The Lancet, Vol.344, No.8921, (August 1994), pp. 521-524, ISSN 0140-6736.

Wolf, G. \& Ritz, E. (2005). Combination therapy with ACE inhibitors and angiotensin II receptor blockers to halt progression of chronic renal disease: pathophysiology and indications. Kidney international, Vol.67, No.3, (March 2005), pp. 799-812, ISSN 0085-2538.

Wong, D.W.; Oudit, G.Y.; Relcd, H.; Kassiri, Z.; Zhou, J.; Liu, Q.C.; Backx, P.H.; Penninger, J.M.; Herzenberg, A.M. \& Scholey, J.W. (2007). Loss of angitensin converting enzyme-2 (ACE2) accelerates diabetic kidney injury. American Journal of Pathology, Vol.171, No.2, (August 2007) pp. 438-451, ISSN 0002-9440.

Xiao, H.D.; Fuchs, S.; Frenzel, K.; Teng, L. \& Bernstein, K.E. (2004). Circulating versus local angiotensin II in blood pressure control: lessons from tissue-specific expression of angiotensin-converting enzyme (ACE). Critical Reviews in Eukaryotic Gene Expression, Vol.14, No.(1-2), (2004), pp. 137-45, ISSN 1045-4403.

Yamada, H.; Akishita, M.; Ito, M.; Tamura, K.; Daviet, L.; Lehtonen, J.Y.; Dzau, V.J.; Horiuchi, M. (1999). AT2 receptor and vascular smooth muscle cell differentiation in vascular development. Hypertension. Vol. 33, No. 6, (June 1999), pp. 1414-1419, ISSN 0194-911X.

Ye, M.; Wysocki, J.; William, J.; Soler, M.J.; Cokic, I. \& Batlle, D. (2006). Glomerular localization and expression of Angiotensin-converting enzyme 2 and Angiotensinconverting enzyme: implications for albuminuria in diabetes. Journal of the American Society of Nephrology, Vol.17, No.11, (November 2006), pp. 3067-3075.

Yusuf, S.; Sleight, P.; Pogue, J.; Bosch, J.; Davies, R. \& Dagenais, G. (2000). Effects of an angiotensin converting-enzyme inhibitor, ramipril, on cardiovascular events in high-risk patients. The Heart Outcomes Prevention Evaluation Study Investigators. New England Journal of Medicine, Vol.342, No.3, (January 2000), pp. 145-153, ISSN 0028-4793.

Zimpelmann, J.; Kumar, D.; Levine, D.Z.; Wehbi, G.; Imig, J.D.; Navar, L.G. \& Burns, K.D. (2000). Early diabetes mellitus stimulates proximal tubule renin mRNA expression in the rat. Kidney International, Vol.58, No.6, (December 2000), pp. 2320-2330, ISSN 0085-2538. 


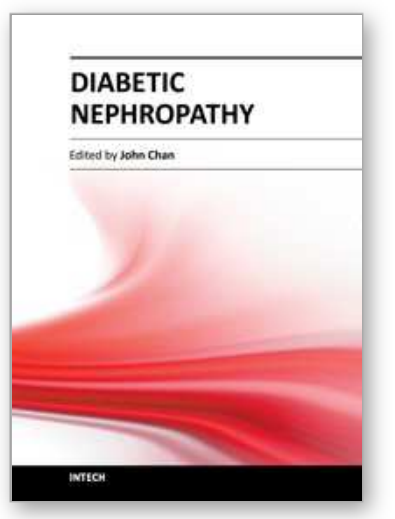

\author{
Diabetic Nephropathy \\ Edited by Dr. John Chan
}

ISBN 978-953-51-0543-5

Hard cover, 166 pages

Publisher InTech

Published online 20, April, 2012

Published in print edition April, 2012

Internationally renowned experts have provided data on their own studies, and discuss the relative usefulness of their work in relation to diabetic nephropathy. The first section describes the novel role of intrarenal reninangiotensin-aldosterone system (RAAS) and oxidative stress in the development of diabetic nephropathy and discusses the current and novel pharmacological interventions in the treatment of diabetic nephropathy. The second section discusses other important contributors outside of the RAAS in the pathogenesis of diabetic nephropathy including AGE/RAGE, epithelial-mesenchymal-transition (EMT) and immune cytokines. Features: Provides novel information on various pathophysiological determinants in the development of diabetic nephropathy Provides novel information on various pharmacological interventions of diabetic nephropathy

\title{
How to reference
}

In order to correctly reference this scholarly work, feel free to copy and paste the following:

Dulce Elena Casarini, Danielle Yuri Arita, Tatiana Sousa Cunha, Fernanda Aparecida Ronchi, Danielle Sanches Aragão, Rodolfo Mattar Rosa, Nadia Sousa Cunha Bertoncello and Fernanda Klein Marcondes (2012). Up-Regulation of Renin-Angiotensin System in Diabetes and Hypertension: Implications on the Development of Diabetic Nephropathy, Diabetic Nephropathy, Dr. John Chan (Ed.), ISBN: 978-953-51-0543-5, InTech, Available from: http://www.intechopen.com/books/diabetic-nephropathy/up-regulation-of-reninangiotensin-system-in-diabetes-mellitus-type-1-angiotensin-i-converting-enzym

\section{INTECH}

open science | open minds

\author{
InTech Europe \\ University Campus STeP Ri \\ Slavka Krautzeka 83/A \\ 51000 Rijeka, Croatia \\ Phone: +385 (51) 770447 \\ Fax: +385 (51) 686166 \\ www.intechopen.com
}

\author{
InTech China \\ Unit 405, Office Block, Hotel Equatorial Shanghai \\ No.65, Yan An Road (West), Shanghai, 200040, China \\ 中国上海市延安西路65号上海国际贵都大饭店办公楼 405 单元 \\ Phone: +86-21-62489820 \\ Fax: $+86-21-62489821$
}


(C) 2012 The Author(s). Licensee IntechOpen. This is an open access article distributed under the terms of the Creative Commons Attribution 3.0 License, which permits unrestricted use, distribution, and reproduction in any medium, provided the original work is properly cited. 